Portland State University

PDXScholar

7-11-1996

\title{
Ottilie: Expression of the Ideal of Romantic Childlikeness in Goethe's Wahlverwandtschaften
}

Melodie Joy Steele

Portland State University

Follow this and additional works at: https://pdxscholar.library.pdx.edu/open_access_etds

Part of the German Language and Literature Commons

Let us know how access to this document benefits you.

\section{Recommended Citation}

Steele, Melodie Joy, "Ottilie: Expression of the Ideal of Romantic Childlikeness in Goethe's Wahlverwandtschaften" (1996). Dissertations and Theses. Paper 5201.

https://doi.org/10.15760/etd.7077

This Thesis is brought to you for free and open access. It has been accepted for inclusion in Dissertations and Theses by an authorized administrator of PDXScholar. Please contact us if we can make this document more accessible: pdxscholar@pdx.edu. 


\section{THESIS APPROVAL}

The abstract and thesis of Melodie Joy Steele for the Master of Arts in German were presented July 11,1996, and accepted by the thesis committee and the department.

COMMITTEE APPROVALS:

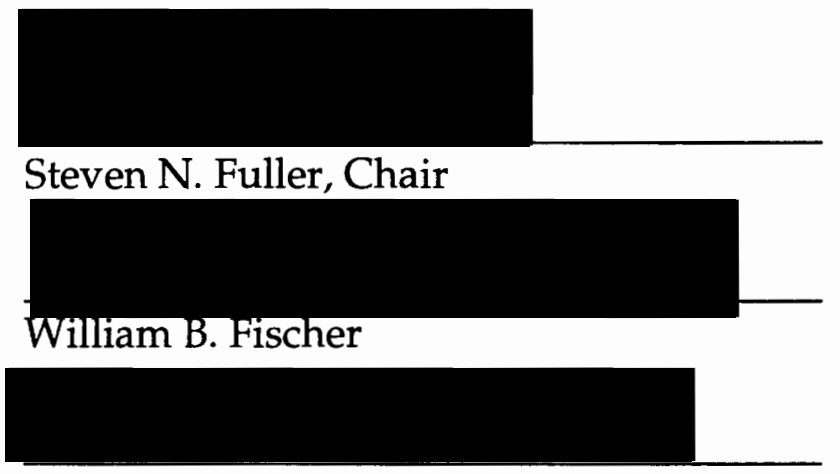

Friedrich E. Schuler

Representative of the Office of Graduate Studies

DEPARTMENT APPROVAL:

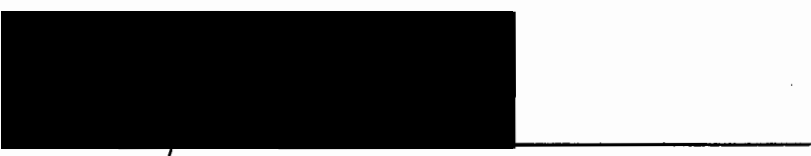

Louis J. Elteto, Chair

Department of Foreign Languages and Literatures

\section{ACCEPTED FOR PORTLAND STATE UNIVERSITY BY THE LIBRARY}

by

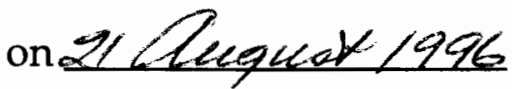




\begin{abstract}
An abstract of the thesis of Melodie Joy Steele for the Master of Arts in German presented July 11, 1996.

Title: Ottilie: Expression of the Ideal of Romantic Childlikeness in Goethe's Wahlverwandtschaften.
\end{abstract}

The interpretation of Ottilie in Goethe's Wahlverwandtschaften stems from an understanding of romantic motifs, which find their most systematic expression in her childlike character. Ottilie embodies the romantic idealization of childhood as a means of withdrawal from the enlightened world, echoing the Romantics' rejection of the disenchanted Age of Enlightenment. Through her portrayal of innocent childlikeness, her adolescent conflict with the rational world, and her final rejection of enlightenment, Ottilie maintains her childlike purity, expressing the romantic ideal of childhood.

Ottilie's childlike emotional disposition puts her in conflict with the enlightened world of adults and academia. In an attempt to maintain her childlike innocence, she separates herself from the present world and establishes ties to the medieval past through monastic duties and catholic sympathies. However, Ottilie's attempt to remain separate is futile due to her enlightened surroundings. Her journey toward self-awareness begins as a 
result of her love for Eduard, whose sexual thoughts of Ottilie launch her into a state of adolescence, against which she unconsciously struggles.

Continual contact with the enlightened world weakens Ottilie's efforts to maintain ties to her childlike state. In her weakened condition she is unable to resist Eduard's continual amorous pursuits and openly displays her affection for him with a kiss. Her inner turmoil, resulting from her deliberate indiscretion causes the accidental drowning of Charlotte's and Eduard's baby Otto, which illuminates the iniquitous nature of her love for Eduard. She makes the decision to reject full enlightenment and transcends her human frailty by becoming saint-like. Through renunciation, which results in her sacrificial death, she spurns enlightenment and returns to a state of everlasting purity.

As the portrayal of the romantic ideal of a maintained childhood innocence, Ottilie seems to be a vehicle to express either Goethe's commendation of condemnation of Romanticism. For the romantic, Ottilie's life and death are a triumph, for she succeeds in passing from this world, having proceeded from innocent child to saint into everlasting life. For the non-romantic, Ottilie's death is a tragedy, for she never reaches true enlightenment and never develops to her full potential. 
OTTILIE: EXPRESSION OF THE IDEAL OF ROMANTIC CHILDLIKENESS IN GOETHE'S WAHLVERWANDTSCHAFTEN

\author{
by \\ MELODIE JOY STEELE
}

A thesis submitted in partial fulfillment of the requirements for the degree of

MASTER OF ARTS

in

GERMAN

Portland State University 1996 


\section{ACKNOWLEDGMENTS}

Much thanks is expressed to Dr. Linda Parshall for introducing me to Die Wahlverwandtschaften and its link to Romanticism, for her encouragement and willingness to be my advisor in absentia;

to my co-advisor Dr. Steven Fuller for his expertise and help in the formation and presentation of my argument and for his demand of excellence;

to Dr. Louis Elteto for his willingness to share his wisdom and insight;

to Dr. Bill Fischer for imparting his valuable knowledge of word processing;

to all of my German professors at Portland State over the years: (in addition to those mentioned above) Ms. Tineke Bierma, Dr. Franz Langhammer, Dr. Timm Menke and Dr. Laureen Nussbaum, for their outstanding instruction and love for the language that was contagious;

to my brother Mark Allen Eaton for his indispensable help with editing and rewriting;

to my family for their never-ending encouragement;

to my husband Terry for his continuing love and support, without which I would not have succeeded. 


\section{CONTENTS}

\section{Page}

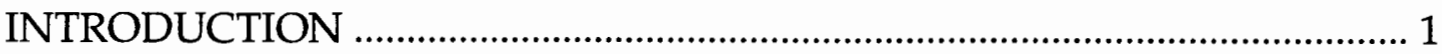

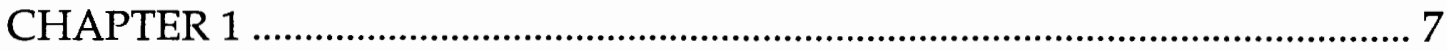

OTTILIE THE CHILD-Innocent and at odds with the Enlightened World

CHAPTER 2

OTTILIE THE ADOLESCENT-Her Struggle between Childhood and Adulthood

CHAPTER 3

OTTILIE THE SAINT-Transcendent and Perfected

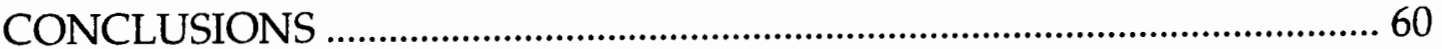

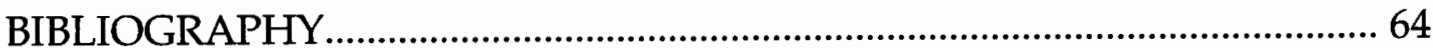




\section{INTRODUCTION}

Goethe's Die Wahlverwandtschaften is perhaps his most impenetrable and multi-faceted work. ${ }^{1}$ In spite of this, critics attempt to attribute a single interpretation to Die Wahlverwandtschaften in hopes of finding a deeper understanding of the work as a whole. Opinions about the novel range from an expression of Goethe's classicism to a sympathetic critique of Romanticism. ${ }^{2}$ These broad opinions allow for a variety of interpretations. The purpose of this study is to come to a conclusion as to the novel's link to Romanticism through an examination of the mysterious and evasive character of Ottilie. The interpretation of the novel hinges upon a correct assessment of Ottilie and her puzzling development-or lack thereof. ${ }^{3}$ Ottilie, whose struggle to maintain her childlikeness in an enlightened world leads to her final refusal of enlightenment, depicts the German Romantics' rejection of the Enlightenment. ${ }^{4}$ Her response to enlightenment facilitates a romantic interpretation of Goethe's Wahlverwandtschaften.

1 Johann Wolfgang von Goethe, Die Wahlverwandtschaften (München: Deutscher Taschenbuch Verlag GmbH \& Co KG, 1991) 293.

2 Stuart Atkins, "Die Wahlverwandtschaften: Novel of German Classicism," GQ 53 (1980): 1. And William J. Lillyman, "Monasticism, Tableau Vivant and Romanticism: Ottilie in Goethe's Die Wahlverwandtschaften," JEGP 81 (1982): 366.

3 Erika Nolan, "Das Wahre Kind der Natur? Zur Gestalt der Ottilie in Goethes Roman Die Wahlverwandtschaften," JbdfdH 81 (1982): 84.

4 The term "childlikeness" is my noun variation of the adjective "childlike." 
On the quest toward an interpretation, critics speak of "real obscurities in Die Wahlverwandtschaften, possibly ambiguities and ambivalences which explain and in part justify divergent opinions." 5 That Goethe's own comments about the work often contradict themselves or are unclear is particularly perplexing when searching for authorial intent. ${ }^{6}$ Goethe, though well-known for his opposition to Romanticism ("Das Klassische nenne ich das Gesunde, das Romantische das Kranke"7), was nevertheless influenced by the romantic Zeitgeist. ${ }^{8}$ Die Wahlverwandtschaften, published in 1809 , was written during the early and middle romantic periods, 1797-1815. Goethe's statement that the novel was "nur für die Zeit gemacht" reinforces his claim that Die Wahlverwandtschaften contained "romantische Mitteilungen." 9 Some have suggested that Goethe seems to have entered upon a romantic phase, maintaining that "the death of Schiller [in 1805] had...helped to emancipate Goethe from his classical phase, so that Die Wahlverwandtschaften appears at first sight to be the work of a romantic writer." 10 Still, "critics of Die Wahlverwandtschaften seem reluctant to draw consistent conclusions from this

\footnotetext{
${ }^{5}$ Henry Hatfield, "Towards the Interpretation of Die Wahlverwandtschaften," GR 23 (1948):107.

6 Hans Reiss, "Mehrdeutigkeit in Goethes Wahlverwandtschaften," Jahrbuch des deutschen Schillergesellschaft 14 (1970): 367.

7 H. G. Barnes, Goethe's Wahlverwandtschaften, a Literary Interpretation (Oxford: Clarendon Press, 1967) 19.

8 Henry Hatfield, "Towards the Interpretation of Die Wahlverwandtschaften," GR 23 (1948): 107.

${ }^{9}$ Stöcklein 65.

10 Barnes 19, 2.
} 
now accepted fact of the poet's romantic phase."11 The novel's link to Romanticism becomes clearer when analyzed in terms of its romantic motifs. These romantic motifs find their most systematic expression in the character of Ottilie, who has been called the romantic counter figure to Goethe's classical figure, Dorothea. ${ }^{12}$

Die Wahlverwandtschaften is the story of the changing relationships among four main characters who are all involved in constructing an English romantic park on the grounds of wealthy landowners, Eduard and Charlotte. Early in the text, Charlotte introduces the reader to her niece, Ottilie. She mentions to her husband that Ottilie is not doing well academically at the boarding school she attends with Charlotte's daughter, Luciane. Charlotte reveals that she intends to invite Ottilie to live with them at the estate and bring her up in domestic affairs. Eduard also invites his friend, the Hauptmann, to come and help them with their construction of the garden. As time progresses, affection grows between Eduard and Ottilie and between Charlotte and the Hauptmann. This affection culminates in a double adultery as Charlotte's and Eduard's thoughts of the Hauptmann and Ottilie, respectively, unite the four of them in mind during Charlotte's and Eduard's conjugal relations. As it becomes outwardly evident that these affections have developed, the Hauptmann leaves the estate. When Charlotte, upon his departure, tells Eduard that she does not want a divorce, Eduard also leaves,

\section{Barnes 20.}

12 From Goethe's epic poem Hermann und Dorothea. Esther Schelling-Schär, Die Gestalt der Ottilie: $z u$ Goethes Wahlverwandtschaften (Zürich u. Freiburg i Breisgau: Atlantis Verlag, 1969) 36. 
to sort things out in his mind, with the stipulation that Charlotte not send Ottilie away. The double adultery results in Charlotte becoming pregnant, though the son born to her resembles the Hauptmann and Ottilie more than his biological parents. Eduard, unable to control his desire to be with Ottilie, returns to the estate to plead with her to marry him. Their mutual consent to kiss agitates Ottilie and results in the accidental drowning of Charlotte's and Eduard's baby, Otto. The tragedy provides the avenue for Ottilie to become partially aware of the sin of her love for Eduard. Realizing that her love for him is responsible for the tragedy, Ottilie embarks on a journey of renunciation that eventually leads to self-starvation, her ultimate rejection of the material world. Having ascended to the status of saint because of her complete renunciation, she dies, providing a substitutionary atonement for the others.

Critics recognize the romantic imagery in Die Wahlverwandtschaften, but with differing opinions. Some believe that the motifs which surround Ottilie's character provide a new perspective from which to consider the novel's relation to Romanticism. ${ }^{13}$ Others maintain that the romantic motifs, although they appear often in Die Wahlverwandtschaften, are incidental. ${ }^{14}$ However, the romantic themes and motifs seem too prevalent and too obvious to be incidental. The main activity at the estate, where most of the action of Die Wahlverwandtschaften takes place, centers on the construction of a park in the style of an English romantic garden, representing an "attempt to withdraw

13 Lillyman, Monasticism 349.

14 Atkins 10. 
from the world of society into an ideal world." 15 This withdrawal from civilization into nature echoes the withdrawal of the Romantics from their enlightened world. Attempts in Die Wahlverwandtschaften to restore the past include the renovation of the chapel to its earlier Baroque splendor, and the reconnecting of the three small ponds into one large lake as it originally had been. These textual events and their connection to the character of Ottilie allow romantic motifs and symbols to come to the fore and strengthen a romantic interpretation of Die Wahlverwandtschaften.

Die Wahlverwandtschaften presents Ottilie as a child figure. Though past childhood, at 17 years of age, Ottilie manifests inherent childlike qualities and is regarded as a child by the other characters. Every child at some point reaches an age of accountability through the acquisition of knowledge. This event, which results in the loss of innocence, re-depicts Adam and Eve eating of the tree of knowledge in the garden of Eden. Like every child, Ottilie undergoes a process of enlightenment against which she struggles, and comes to a place where she receives partial knowledge. Upon acquiring that knowledge, Ottilie, like other romantic characters, must embark upon a journey in search of a way to regain her state of purity, a process expatiated by Heinrich von Kleist's essay Über das Marionettentheater (1810). Once a child becomes enlightened, it can no longer return to its state of innocence, but must seek redemption through a return to purity by way of a new and different avenue. Likening the world's development to the Fall in the Garden of Eden, the Romantics claimed that a similar process had occurred over the recent

15 F. J. Stopp, "Ein Wahrer Narziß: Reflections on the Eduard--Ottilie Relationship in Goethe's Wahlverwandtschaften," PEGS 29 (1959-60): 67. 
centuries. Once childlike, in the darkness of the Middle Ages, the world had also lost its innocence due to the coming of the Enlightenment. The Romantics, in their desire to maintain a state of childlike incredulity, idealized the child figure and sought to establish a connection to the vanished age of innocence. Ottilie's character embodies the romantic idealization of childhood as a means of withdrawal from the enlightened world. Through her portrayal of innocent childlikeness, her adolescent conflict with enlightenment, and her final rejection of the enlightenment process, she succeeds in maintaining her romantic childlikeness. 


\section{CHAPTER 1}

\section{OTTILIE THE CHILD—INNOCENT AND AT ODDS WITH THE ENLIGHTENED WORLD}

Through a Romantisierung of the world, the Romantics hoped to return to a time unspoiled by the Enlightenment. The Romantics believed that the world had become disenchanted due to an enlightened Depoetisationsprozeß which held that everything could be explained rationally and scientifically. Romantic author and philosopher August Wilhelm Schlegel maintained that “Der Depoetisationsprozeß hat freilich lange genug gedauert, es ist einmal Zeit, daß Luft, Feuer, Wasser, Erde wieder poetisiert werden."16 Similarly, Novalis expressed the aim of the Romantics, writing “Die Welt muß romantisiert werden."17

A romantic perception, however, was dependent upon one's inner, albeit subjective perspective. True Romantisierung could be realized only through the eyes of a child-in order to see the magic in nature, one had to view it from a child's perspective, one in which reason does not outweigh mystery and wonder. The figure of the child is central to Romanticism in that the state of childhood depicts the stage of the world before the Depoetisierung of the Age of Enlightenment. The romantic ideal of childhood is for a child "to

16 Eckart Kleßmann, Die deutsche Romantik (Köln: DuMont Buchverlag, 1979) 79.

17 Novalis, "Die Welt muß romantisiert werden," Die deutsche Literatur in Text und Darstellung, Romantik I, Band 8, eds. Otto F. Best and Hans-Jürgen Schmitt (Stuttgart: Philipp Reclam jun. GmbH \& Co., 1974) 57. 
remain a child, to not grow up, for growing up is a reenactment of the Fall [of man]." 18 The despotism of reason could only be wiped away by a return to childlike innocence.

Although Goethe's Die Wahlverwandtschaften is not universally regarded as a romantic work, the character of Ottilie expresses the romantic ideal of innocent, pre-lapsarian childlikeness. While not a child in years, Ottilie displays traits and sentiments reminiscent of the vanished age of innocence. She is able to experience the world as a romantic because she is not enlightened. As a representation of the child figure, her sensitive and naive character reflects the traits that characterize the pre-enlightened state of innocence. The narrator's assessment of her personality, as well as the treatment of Ottilie by the other characters, confirms her childlike disposition. In a world of reason and sophistication, her childlikeness causes her to be at odds with her otherwise rational surroundings. Sensing this displacement, she attempts to separate herself from the present world by withdrawing into subjectivity and a self-conceived idealization of the past. Ottilie seeks to maintain a tie to innocence by establishing a connection to the vanished golden Middle Ages by a monastic lifestyle and other expressions of Catholic sympathies. Her response is reminiscent of the early German Romantics who idealized the childlike condition and sought to maintain a state of innocence as a refuge from the enlightened world in a recollection of the past-a "Rückbesinnung auf das Vergangene." 19 Ottilie represents the romantic ideal of childhood and the attempt to re-enchant and re-poeticize the world.

18 Lillyman, Monasticism 365.

19 Kleßmann 7. 
The narrator and the characters in Die Wahlverwandtschaften attest to Ottilie's childlikeness. The narrator constantly refers to her as "das gute Kind," "das liebe Kind," and "das herrliche Kind." $20 \mathrm{He}$ attributes childlike characteristics to her, describing her as simple and naive, displaying a "frische[s] Gemüt" (I, 10, 79). ${ }^{21}$ Similarly, the Vorsteherin of the boarding school that Ottilie attends admits that Ottilie is a "schön und liebes Kind" (I, 3, 26), and even Eduard, owner of the estate and Ottilie's spiritual lover, calls her "liebes Kind" (I, 9, 67). Not only do the other characters refer to her as a child, they treat her like one. Charlotte and the other adults wish to protect Ottilie from the evils of the world. For example, Charlotte tries to hide from Ottilie the fact of her guests' extra-marital affair, "um Ottiliens willen. Das gute reine Kind sollte ein solches Beispiel so früh nicht gewahr werden" $(I, 10,68)$. Both Charlotte and Eduard express concern about sending Ottilie out into the world to be among strangers. The narrator and the other characters perceive her as a child whose innocence needs protection.

We know little about Ottilie's physical appearance, only that she is beautiful. The sole feature that the narrator mentions are her eyes, which are the same color as Otto's, Charlotte and Eduard's infant son. The narrator describes these eyes as "zwei große schwarze durchdringende Augen, tief und freundlich" (II, 13, 224). Not only are the child's eyes the same color as Ottilie's, they are an exact resemblance, connecting Ottilie to Otto as a

20 Patricia Drake, “Ottilie Revisited," GQ 26 (1953): 248.

21 Johann Wolfgang von Goethe, Die Wahlverwandtschaften (Stuttgart: Philipp Reclam jun., 1956) 21 . Hereafter cited only in the text as above, with part, chapter, and page number in parentheses. 
Doppelgänger. When Ottilie looks into Otto's eyes for the first time, she "glaubte in ihre eigenen zu sehen" (II, 8, 189). The dark eyes symbolize the pre-enlightened state of a child. As a child still in darkness, Ottilie is unable to comprehend the things of the enlightened world; her intellectual eyes are not yet open. "Die in Schulfächer aufgeteilte Wirklichkeit versteht Ottilie nicht. Ein tieferes Verständnis wohnt ihr inne, ein Verständnis, das nicht geprüft werden kann." 22 She sees not as an enlightened person, but through the eyes of a child with a deeper understanding of the world based on intuition rather than reason.

Because Ottilie possesses an intuitive rather than a cognitive understanding of things, she is more attuned to emotion than to reason. The narrator describes her as a character of "zartem aufgeregtem Gemüt" (I, 15, 103), who "mehr ahnete als sah" (II, 10, 200). Ottilie, in "halbbewußter Jugend" (II, 10, 200), displays the emotional sensitivity of a child who is governed by feeling rather than reason. This pre-enlightened emotionalism is key to the philosophy of the German Romantics. Friedrich Schlegel, in his Gespräch über die Poesie (1800), describes "Romantik" as that, "wo das Gefühl herrscht, und zwar nicht ein sinnliches sondern das geistige." 23 Ottilie's natural emotional disposition causes her to disdain the rational. She is ruled and swayed by her emotions, especially in regard to her relationship with Eduard.

22 Schelling-Schär 16.

${ }^{23}$ Kleßmann 12. 
Ottilie's immaturity causes her to be at odds with adults, those who have left the pre-enlightened state of childhood. If "the child" represents innocence and emotion, then "the adult" represents enlightenment and reason. Ottilie opposes reason and therefore stands outside of the adults' circle, creating her own world, absorbed in household activities, as an innocent among the enlightened. She does not enter into the adults' conversation, but remains quiet and observant, as a child who is seen and not heard. In turn, the adults adjust their conversation to her scope of knowledge. Though admitting to being the least enlightened among them, Eduard contrasts his and the other adults' enlightened state with those "die nur dunkel vor sich hinleben...," describing his group as "...solchen, die schon durch Erfahrung aufgeklärt sich mehr bewußt sind" $(I, 1,9)$. Ottilie belongs to those who are in darkness; her dark eyes identify her with those who have not been enlightened.

Ottilie's emotional state puts her at odds with the academic world as well. Because academia represents an expression of reason, and reason a product of the enlightened world, an introspective child is not well-suited for the academic realm. The Gehülfe at Ottilie's boarding school admits that Ottilie learns the way a small child would, always having to start at the beginning and moving slowly forward, taking tiny steps. She is unable to keep up with the other students. Instead she is dependent upon others to explain things and to find the necessary links that aid understanding. She is unable to make logical progress or to grasp things of which she has had no prior knowledge or experience. In regard to the school examinations, the Gehülfe remarks that Ottilie knows much, yet when one asks her a question, she appears to know 
nothing at all, responding much the way a child does when interrogated. She displays a lack of judgment. In an art competition, she is unable to finish her drawing because she undertakes too large a project, and she uses the childish excuse of a headache as reason for her poor performance. Her headaches are the physical manifestation of a psychic disorder, symbolizing her conflict with the academic world and her innate aversion to reason and to rational thinking, which causes her pain. Later, those headaches will continue, revealing the inner turmoil she will suffer as an adolescent. As an emotional child, the stress of academia results in Ottilie's physical suffering, which signals her conflict with reason itself.

Ottilie's lack of success with academics is indicative of her position within the enlightened world at large. We learn from the remarks of the Vorsteherin and others at the school that Ottilie has no chance for success in the academic realm. In regard to Ottilie's hidden ability, the vorsitzende Prüfende exclaims, "Fähigkeiten werden vorausgesetzt, sie sollen $\mathrm{zu}$ Fertigkeiten werden. Dies ist der Zweck aller Erziehung" (I, 5, 41). Ottilie's continual struggle has no merit in the world's system of education that insists upon success and maturity. The need for completion contradicts a central tenet of Romanticism: fulfillment comes through the process of striving, not in the achieved goal. "Romantik ist auch Aufbruch, getrieben von Unrast, auf der Suche nach einem festen Ziel und Geborgenheit, dessen Unerreichbarkeit geahnt wird." 24 The goal is unattainable. Friedrich Schlegel, in a 1798 article for Athenäum, claimed "Die romantische Dichtart ist noch im Werden, ja, das

${ }^{24}$ Kleßmann 148. 
ist ihr eigentliches Wesen, daß sie ewig nur werden, nie vollendet sein kann." 25 Those at the school, as part of the enlightened world, are impatient for Ottilie to grow up, yet Ottilie cannot reach this state of maturity and completion due to her childlikeness. "With Goethe it is the becoming not the being which constitutes the essence of human character [my italics]. Ottilie is one of the poetic expressions of this mystery." 26 She is the child who does not belong to the world's system that demands success and completion, rather she is an expression of the romantic concept of the immer Werdende.

Ottilie's childlike character sharply contrasts the enlightened character of Charlotte's daughter, Luciane, "das Gegenbild zu Ottilie...eine Mondäne in der Gesellschaft [my italics]."27 Luciane is a star of the academic world, who learns easily and who "...alles vergißt und im Augenblicke sich an alles erinnert" (I, 2, 12). We learn from Charlotte that Luciane was "...für die Welt geboren," and that she "bildet sich für die Welt" $(\mathrm{I}, 2,12)$ [my italics]. Luciane, representative of the world of reason, contrasts Ottilie who was not born for the world, but was "zum Wohl, zur Zufriedenheit anderer...geboren ward" (I, 3,26 ). Ottilie cannot adapt to the world of reason and enlightenment because of her inherent childlikeness. The juxtaposition of Ottilie with the enlightened figure of Luciane reinforces Ottilie's position as the romantic child.

25 Friedrich Schlegel, “Progressive Universalpoesie," Die deutsche Literatur in Text und Darstellung, Romantik I, Band 8, eds. Otto F. Best and Hans-Jürgen Schmitt (Stuttgart: Philipp Reclam jun. GmbH \& Co., 1974) 24.

26 Keith Dickson, “The Temporal Structure of Die Wahlverwandtschaften," GR 41 (1966): 182.

27Ernst Beutler, "Nachwort," Die Wahlverwandtschaften (Stuttgart: Philipp Reclam jun., 1956): 265. 
Ottilie's emotional state enables her to experience the romantic child's affinity to nature. "Diese [romantische] Landschaft ist beseelt und zugleich auch Seelenspiegel." 28 Also "die Landschaft is angeblich eine 'Landschaft der Seele," and "die Landschaft und Atmosphäre...wird symbolisch und mit Ottilie's Seelenleben erklärt." 29 From a romantic perspective, such a special relationship to nature was the child's experience only. When a child approaches adulthood, this affinity to nature changes. This change portrays the coming of age as a reenactment of the Fall from grace. Nature was not at odds with humankind until after the Fall, just as nature's special relationship to the child was seen to be intact until the child reached awareness. A child's pre-enlightened eyes see the natural world as a realm of fantasy. To those who are innocent children, nature is a "Narnia," 30 a realm of wonder with speaking plants and animals, an experience demonstrated by characters of romantic novels, for example Bertha in Tieck's Der Blonde Eckbert (1797), Heinrich in Novalis' Heinrich von Ofterdingen (1802), Eichendorff's Taugenichts (1826), and not to exclude the son in Goethe's Erlkönig (1780). Ottilie likewise hears nature's voices, remarking that "Die Vögel sprechen zu uns, von Jugend auf, und wir lernen ihre Sprache verstehen" (II, 7, 183). Her childlikeness enables her to possess a special tie to nature and hear the voices of nature silenced in adults by their rational, enlightened perception.

\footnotetext{
28 Kleßmann 89.

29 Ignace Feuerlicht, "Der Erzähler und das 'Tagebuch' in Goethes Wahlverwandtschaften," GJb 103 (1986): 338.

30 C.S. Lewis' Chronicles of Narnia depicts the spiritual world as a world between the worlds in the land of "Narnia," a realm in which children experience speaking plants and animals.
} 
This childlike incredulity and responsiveness to nature is unique to Ottilie among the characters of Die Wahlverwandtschaften. Once Ottilie is removed from the school's rational and social surroundings, her affinity to nature manifests itself. She who once spent her time indoors, now cannot stay inside, but instead "eilt...mit Sonnenaufgang aus dem Hause..." (I, 17, 117). She has an abundant knowledge of trees and flowers, and visits the gardens frequently, taking a great interest in the greenhouses. There, she exhibits quiet and consistent activity, mirroring the way nature works, moving in a perpetual motion, as if she herself were a part of nature. "Um die Natur zu erkennen, müßte [der Mensch] sie selbst sein." 31 Thomas Mann asserts that Ottilie is:

“das süßeste Kind der Natur, das je von eines Künstlers Hand gebildet wurde. Sie hat in ihrer Sanftmut, ihrer lächelnden Stummheit und nachtwandlerischen Lieblichkeit, von einem Elementarwesen der Romantik, einer Undine, nicht wenig, ihre sympathetische Naturverbundenheit ist recht aus dem Herzen ihres Dichters erfunden, dessen Liebe sie atmosphärisch umgibt." 32

By likening her to an Undine, Mann asserts Ottilie's magical unity with the elements. Undine was a part of nature; her fairy-tale half-human/ half-fish character had a magical tie to water. Similarly Ottilie possesses a mysterious romantic affinity to nature through her intimate relationship with the earth.

Ottilie's oneness with nature allows her to experience nature's magic, a mysterious phenomenon peculiar to characters in romantic novels. She habitually avoids the path that contains traces of coal, complaining to suffer

\section{Schelling-Schär 34 .}

32 Thomas Mann, "Zu Goethes Wahlverwandtschaften," Gesammelte Werke, Band IX (Frankfurt am Main: S. Fischer Verlag, 1960) 184-85. 
from headaches and chills whenever she walks there. Her negative reaction to coal as the symbol of industrialization expresses her aversion to a product of the Age of Enlightenment. English visitors to the estate confirm her affinity to the earth by means of a scientific pendulum experiment, in which they convince Ottilie to participate. This experiment, which is meant to determine the relationship between organic and inorganic materials, exposes the pendulum's effect on Ottilie and in turn Ottilie's magical effect over the metals. ${ }^{33}$ Though she holds the pendulum "...noch ruhiger, unbefangener, unbewußter..." (II, 11, 213) than the others, it immediately begins to swing involuntarily. As a result of the swinging motion, she develops a headache. This reciprocal effect is evidence of Ottilie's affinity to nature. "The result of the pendulum experiment indicates that there is some kind of elemental affinity between Ottilie and what lies hidden both in the earth and in the human soul." ${ }^{34}$ Ottilie's tie to nature results in displays of forces that science cannot grasp. Nature mirrors and evokes Ottilie's emotions in a reciprocal manner, a phenomenon common to romantic characters.

For the Romantics, nature was the place to discover and express emotion. For romantic painter Friedrich Overbeck it was the place to rediscover one's "Herz, Seele, Empfindung." In response to Overbeck's question, "wo soll man also dieses unerreichbar Scheinende suchen?" he answers, "Da wo [Raffael] es gesucht und gefunden hat-in der Natur und in

33 Johann Wolfgang von Goethe, Die Wahlverwandtschaften, trans. Elizabeth Mayer and Louise Bogan (Westport, CT: Greenwood Press, 1976) 302.

34 Eric Blackall, Goethe and the Novel (Ithaca: Cornell University Press, 1976) 168. 
einem reinen Herzen." 35 Ottilie's innocence and pure heart allow her to directly experience the wonder of nature, unencumbered because of her sinless heart. The beauty of the flowers stirs her emotions. "Mit welchen Empfindungen betrachtete Ottilie die späteren Blumen, die sich erst anzeigten" $(I, 17,116$.$) . She found nature conducive to expressing emotion,$ strolling in the garden, finding "Raum, sich in der Einsamkeit auszuweinen" (II, 10, 201). Ottilie's immediate relationship to nature enables her to express and experience romantic emotions.

However, Ottilie's tie to nature in turn alienates her from civilization. Because she is in conflict with the enlightened world, she desires to remain separate from it and to maintain her childlike state by not growing up. Her display of bowing low to Charlotte upon arriving at the estate expresses this desire by demonstrating the relationship she wishes for Charlotte and herself. When asked for the reason for such humility, Ottilie replies, "Es ist so demütig nicht gemeint...ich mag mich nur so gern jener Zeit erinnern, da ich noch nicht höher reichte als bis an Ihre Kniee..." (I, 6, 44). She wants to retain her position as the child in relationship to the adult characters. Later she refuses to be sent into the "große Welt" (II, 15, 234) and feels compelled to maintain her innocence in that she "ihren Blick wegwenden durfte, ja mußte, von dem was sie nicht sehen mochte und sollte" (II, 10, 200). Ottilie feels obligated to maintain her innocence and considers it her "Schicksal, als eine arme Waise in der Welt geblieben zu sein" (II, 14, 231). Her alienation from the world is not

35 In a letter to his father in 1808 , as quoted in Kleßmann 58. 
merely a product of circumstance; it is her own choice, reflecting the similar reactions of the German Romantics to the Age of Reason.

Because Ottilie is incapable of adapting to the enlightened world, she rejects it and attempts to remain separate from it. This process of alienation from the enlightened world and her subsequent withdrawal into a supposedly golden age of innocence portrays the epitome of the romantic ideal. Not only does Ottilie desire to separate herself from the enlightened world, she refuses to become part of it. Eduard offers an illustration of her desire to remain separate in the discussion of the elective affinities in chapter four. He refers to the mixing together of water, wine, oil and mercury and makes the statement that some elements join easily as do wine and water, yet some such as oil will refuse to let themselves be joined "but will remain detached like strangers." 36 "Dagegen werden andre fremd nebeneinander verharren und selbst durch mechanisches Mischen und Reiben sich keinesweges verbinden" (I, 4, 34). Though Ottilie will be enticed by the enlightened world, she will ultimately succeed in remaining separate from it.

Illustrative of Ottilie's refusal to be joined to the enlightened world is her refusal to deliberately change her childlike handwriting. The Gehülfe relays to Charlotte that there had been complaints about Ottilie's handwriting and that she wrote "langsam und steif" (I, 3, 27). Charlotte, trying to remedy this, "schob ihr manchmal abgeschriebene Federn unter, um sie auf einen freieren Zug der Handschrift zu leiten" (I, 6, 44-45), yet she always found the pens resharpened. Ottilie's refusal to change her childlike handwriting signifies her

36 Mayer and Bogan 157. 
refusal to leave the comforts of her childlike state and become a part of the enlightened world of adults.

Ottilie possesses no tie to this present world of reason, rather a tie to the past age of innocence. The narrator describes Ottilie as belonging to a vanished golden age: "einem verschwundenen goldenen Zeitalter" (II, 2, 134). It is natural that childlike Ottilie should feel at home in the golden age of innocence-as Novalis expressed, "Wo Kinder sind, da ist ein goldenes Zeitalter." 37 The Narrator observes that she (and perhaps she only) felt at home among those who looked back to such a time period: "Nach einer solchen Region blicken wohl die Meisten, wie nach einem verschwundenen goldenen Zeitalter, nach einem verlorenen Paradiese hin. Nur vielleicht Ottilie war in dem Fall sich unter ihresgleichen zu fühlen" (II, 2, 134). Because of her inherent childlikeness, Ottilie is the only character in the novel able to possess a tie to this vanished golden age.

Ottilie's innocence represents the supposed innocence of the Middle Ages, which the Romantics like Novalis postulated. Like Ottilie, the Romantics, having become disenchanted and blaming the Enlightenment for the undesirable state of the world, turned back to the past to find refuge in the vanished Middle Ages. They attributed the tragic outcome of the French Revolution to effects of the Enlightenment. "Für Novalis war die Französische Revolution die natürliche Konsequenz eines rationalistischen Zeitalters der Aufklärung." ${ }^{\prime 38}$ As is often the case in a time of great disappointment with the

\footnotetext{
37 Kleßmann 161.
}

38 Kleßmann 17. 
present world, individuals seek consolation in the glorification of the past. “Für die Romantiker lag die Zukunft in der Vergangenheit.... Ihre Zukunft sahen die Romantiker in einem wieder zu erneuernden Mittelalter, freilich einem Mittelalter, das es in der von ihnen postulierten Idealgestalt nie gegeben hatte." 39 The Romantics idealized the Middle Ages for its supposed emotion, innocence and unity. A child figure, like Ottilie, perfectly represents the state of the world before it had reached maturity or become enlightened. Her character depicts the child who loses its tie to this golden age due to the loss of innocence when it acquires knowledge, just the way the romantics claimed the world did when it encountered the Enlightenment.

Ottilie's innocent state is one of unstained spiritual purity, giving her a tie to the religion of the Middle Ages. Novalis idealized the pre-Reformation period for its religious harmony, referring to this time as "schöne glänzende Zeiten, wo Europa ein christliches Land war." 40 He blamed the Reformation for the Depoetisationsprozeß, believing that religion had also become disenchanted; innocence had given way to reason; mystery to rationale. He claimed that a Romantisierung of nature could serve to enhance religion as well. When one sees the wonder, not the rational, in nature, one turns one's thoughts toward God, not toward science and reason. Ottilie, having this childlike view of nature is able to approach religion in the purest way. Romantic painter Philip Otto Runge expressed, "anknüpfend an ein Jesus-

\footnotetext{
${ }^{39}$ Kleßmann 16.
}

40 Novalis, "Die Christenheit oder Europa," Die deutsche Literatur in Text und Darstellung, Romantik I, Band 8, eds. Otto F. Best and Hans-Jürgen Schmitt (Stuttgart: Philipp Reclam jun. $\mathrm{GmbH} \&$ Co., 1974) 161. 
Wort: »Kinder müssen wir werden, wenn wir das Beste erreichen wollen.«"41 About the child Otto, the narrator says that he "sah die Welt schon so verständig an" (II, 13, 224), echoing Novalis' claim that "Ein Kind ist weit klüger und weiser als ein Erwachsener." 42 As a child, Otto understood not the enlightened world, but a higher reality-the spiritual in the nature all around him. ${ }^{43}$ The enlightened individual cannot have this perspective because innocence is lost in the obtaining of knowledge. Because of Ottilie's position as the child, she also possesses this spiritual perception, and thus is the only character "capable of spiritual development." 44 The other characters, having been enlightened, cannot seek God with a pure heart; Ottilie alone has this tie to religion due to her pre-enlightened condition.

Because of Ottilie's conflict with the age in which she lives, she seeks to create a tie to the simplicity and harmony of the past by turning back to a time before the Enlightenment. She accomplishes this through a tie to the Catholicism of the Middle Ages expressed by her monastic lifestyle, creating for herself a world of asceticism. ${ }^{45}$ She behaves in many ways as if she were a

41 Kleßmann 161. The "Jesus Wort to which this statement is bound" comes from Matthew 10:15: "Let the little children come to me, and do not hinder them, for the kingdom of God belongs to such as these. I tell you the truth, anyone who will not receive the kingdom of God like a little child will never enter it." All biblical references taken from the New International Version (Grand Rapids: Zondervan, 1984).

42 Novalis, "Fragmente zur Poetik," Die deutsche Literatur in Text und Darstellung, Romantik I, Band 8, eds. Otto F. Best and Hans-Jürgen Schmitt (Stuttgart: Philipp Reclam jun. GmbH \& Co., 1974) 257.

43 This echoes another "Jesus Wort" from Matthew 11:25: "You have hidden these things from the wise and learned and revealed them to little children."

44 Dickson 183.

45 Lillyman, Monasticism 361. 
part of some monastic order, reminiscent of the Brüderschaften of romantic artists, for example die Nazarener, who sought to reproduce the artwork of the Renaissance masters while living together as monks, separate from society. Ottilie is never idle, but lives a life of service to others. Displaying a romantic asceticism, she practices abstinence. Her "große Mäßigkeit im Essen und Trinken" $(I, 3,25)$ causes Charlotte and those at the school to be concerned. She dresses simply; only at Charlotte's insistence does she change the modesty of her dress and make some new clothes for herself. She deprives herself of material possessions and refuses to accept gifts; she denies herself pleasure, often forgoing dessert. She endures pain silently. The Gehülfe relays to Charlotte that when Ottilie suffers intensely from her headaches, "niemand kann es wissen; denn Ottilie verändert das Gesicht nicht, und ich habe auch nicht gesehen, daß sie einmal die Hand nach dem Schlafe zu bewegt hätte" (I, $5,41-42)$. Her behavior is almost stoic. The narrator calls her "das gute, tätige Kind" $(I, 6,45)$. She performs many duties and tasks for others, including the copying of a manuscript for Eduard in which her handwriting takes on the form of the original document, much the way in which scribes were to copy the Holy Scriptures. These monastic duties connect her to the Catholicism of the Middle Ages and help to separate her from the present world.

In the same way, Ottilie maintains her tie to the vanished Middle Ages through activities which express a Catholic sympathy. Her "instinctive monasticism represents an adoption of aspects of Catholicism in a Protestant world." This process, called "romantic Catholicising" involved "making a cult of the Middle ages....a desire for restoration of the past and a rejection of the present." Ottilie attempts to restore the Catholic past through the restoration 
of the chapel in the Baroque style, an activity of the Counter Reformation, which signified a reaffirmation of Catholicism. "For Goethe a central characteristic of Romanticism was its inclination to Catholicism calling it 'das neukatholische Künstlerwesen."46 Ottilie's Catholic sympathies and her monastic activity give her a tie to a pre-Protestant world.

Ottilie's silent manner communicates the ambiance of medieval spirituality. She leads a quiet life, speaking not with words so much as with gestures, refusing to communicate verbally with language, the agent of reason. Her signature gesture, in which she clasps her hands together and leans slightly forward is "the traditional posture of Christian prayerillustrated throughout Christian art but especially in the Catholic tradition of Medieval and Renaissance Periods." 47 This posture is further evidence of her innate piety. In silence she observes and reproduces the routines of the household. With gestures she communicates to her staff the protocol for the serving of dinner: "Das ruhig aufmerksame Kind verstand sich mit dem Haushofmeister durch Blick und Wink..." (I, 10, 74). By maintaining an air of silence, she distances herself from those around her, removing herself from the enlightened world. Ottilie's silence also alienates her from the reader. "Her natural mode is silence and almost everything we know about her is told us by others." 48 Her unobtrusive silence contrasts Luciane's loquacity and demand for attention from those around her. Ottilie's spirituality does not

\footnotetext{
46 Lillyman, Monasticism 361 \& 362.

47 Lillyman, Monasticism 350.

48 Blackall 179.
} 
announce itself and has no need to do so; true spirituality proclaims itself through actions rather than words. Ottilie separates herself from the world through silence and establishes a connection to the Catholicism of the Middle Ages through the use of gestures.

Her monastic silence denotes her pre-enlightened condition of childlike innocence. The statement: "Das Bewußtsein der Menschen spricht durch das Wort; das Unbewußte durch die Gebärde," 49 fittingly describes the child who has nothing to say since it has not yet reached a certain level of awareness. If gesture is the communication of the unconscious, then Ottilie as unbewußt is able to communicate most effectively through gesture. We see no outward evidence of her Bewußtsein. The Gehülfe admits "wie wenig die gute Ottilie das $\mathrm{zu}$ äußern im Stande ist, was in ihr liegt und was sie vermag" (I, 4, 40). Ottilie's Tagebuch which is supposed to give the reader a glimpse into her inner thoughts-“einen Blick...in ihr Inneres" $(I, 18,125)$, is merely a collection of "Maximen und Sentenzen," 50 a catechism of sorts, with very little personal commentary. Perhaps the glimpse the reader is to receive is the realization that Ottilie, as a child who is "unbewußt," is incapable of forming and expressing her own thoughts. Her silence confirms that she has not yet reached awareness through the process of enlightenment.

Ottilie, as the representation of the child figure, expresses the position and plight of the Romantic in the Age of Reason and Enlightenment. The state of the child is likened to a paradise lost, a vanished golden age, juxtaposed to

\section{Stöcklein 31.}

50 William J. Lillyman, "Affinity, Innocence and Tragedy: The Narrator and Ottilie in Goethe's Die Wahlverwandtschaften," GQ 53 (1980): 54. 
the present enlightened world. Ottilie maintains her childlike state, refusing to adapt to this world, desiring to establish ties to the medieval past through monastic duties and manifestation of Catholic sympathies. Through maintaining a childlike consciousness she is able to have a romantic perception of nature and is able to attain true spirituality, innocence and purity. Ottilie manifests the romantic ideal of a child. Her character expresses the romantic desire of retaining childlike innocence before the Fall, and a desire to return to the Garden of Eden of childhood. 


\section{CHAPTER 2}

\section{OTTILIE THE ADOLESCENT-HER STRUGGLE BETWEEN CHILDHOOD}

\section{AND ADULTHOOD}

Ottilie's attempt to live solely in the past is destined to fail. Her embodiment of romantic childlikeness puts her in conflict with the contemporary enlightened world. Although she desires to remain separate, she is unable to maintain her childlike innocence completely, due to continual contact with the enlightened world around her that weakens her ties to innocence. "The novel concentrates on a hidden, ambiguous, but ultimately decisive growth of self-awareness in Ottilie," though this growth occurs without her knowledge. 51 The reader watches her blindly struggle to maintain her innocence in the world of reason. Though she tries by her monastic lifestyle to remain completely separate from the enlightened world, she does not succeed in remaining unaffected and unaltered by her surroundings. Charlotte reminds her that "Klöster haben wir nicht" (II, 15, 235). The flaw of the romantic Rückkehr was that one is not able to divorce oneself completely from one's environment. As childlike characters in romantic novels commonly experience, Ottilie comes to a place where she encounters enlightenment and must make a decision regarding her further development. Ottilie's exposure to enlightenment is inevitable due to her enlightened surroundings.

51 Alexander Gelley, “Ottilie and Symbolic Representation in Die Wahlverwandtschaften,” Orbis Litterarum 42 (1987): 250. 
Though Ottilie has been exposed to the enlightened world at the school and at the estate, she begins her own journey toward self-awareness as a result of her relationship to Eduard. While starting as an innocent affection, their love for each other grows, being consummated in Eduard's mind during intercourse with his wife. A double adultery results due to Charlotte's simultaneous thoughts of the Hauptmann, Eduard's friend, who is also residing at the estate. Through Eduard's thoughts, Ottilie loses her innocence vicariously, not experientially. The double adultery, of which Ottilie has no knowledge, mysteriously succeeds in changing aspects of Ottilie's character from those of an innocent child to those of an adolescent, as if she herself had taken part physically. A state of adolescence results, followed by her struggle to reconcile these conflicting characteristics, while also allowing her to further develop and explore her romantic qualities. Without Ottilie's knowledge, the double adultery begins the growth process, changing aspects of Ottilie's character from those of a child to those of an adult. Though Ottilie is quite unaware of the spiritual adultery, it succeeds in launching her into the process of maturation.

The mysterious changing effect of the double adultery on Ottilie's character reveals itself in Ottilie's handwriting. Though Ottilie is not present with Eduard in body, the union of husband and wife, whose thoughts unite them with Ottilie and the Hauptmann, respectively, has a magical effect on the document Ottilie is copying at that same moment. When Ottilie presents the manuscript to Eduard the next day, he examines the pages and notices the change in handwriting that occurs as Ottilie's hand becomes his as the pages unfold. 
“...er besah die Abschrift. Die ersten Blätter waren mit der größten Sorgfalt, mit einer zarten weiblichen Hand geschrieben; dann schienen sich die Züge zu verändern, leichter und freier zu werden: aber wie erstaunt war er, als er die letzten Seiten mit den Augen überlief! Um Gottes willen! rief er aus, was ist das? Das ist meine Hand!" (I, 12, 8788).

Upon later reviewing the document, Eduard notices again Ottilie's "kindlich, schüchterner Hand $(I, 13,91)$ " that occupies that first few pages and the contrast between those pages and the last few, which contain the handwriting of an adult, of himself, symbolic of Ottilie's process of maturation and their oneness. What Charlotte had hoped to accomplish earlier with Ottilie's handwriting, occurs mysteriously though not coincidentally on the night when Eduard's thoughts involve Ottilie in an adult act of passion. Her changed handwriting bears witness to her maturing process.

The altered handwriting exposes the unsanctioned love between Eduard and Ottilie. Upon seeing the union of his and Ottilie's handwriting, Eduard exclaims "Du liebst mich" (I, 12,88), and she does not deny it. In fact the narrator adds that it would have been impossible to determine who embraced the other first. "Wer das andere zuerst ergriffen, wäre nicht zu unterscheiden gewesen"(I, 12, 88). Although Ottilie commits no sin outwardly, she betrays Charlotte in her heart by allowing herself to love Eduard, Charlotte's husband. According to biblical doctrine, the sin of the heart (lust) is no less sinful than the sin of the flesh (adultery)..$^{52}$ Eduard himself proclaims

\footnotetext{
52 Matthew 5:28: "But I tell you that anyone who looks at a woman lustfully has already committed adultery with her in his heart." Goethe used this verse to explain the purpose for Die Wahlverwandtschaften: "Der einfache Text dieses Büchleins," schrieb Goethe am 7. September 1821 an Zauper,... "sind die Worte Christi: 'Wer ein Weib ansieht, ihrer zu begehren.' Ich weiß nicht, ob irgend jemand sie in dieser Paraphrase wiedererkannt hat."
} 
(and Ottilie does not disagree) that though "Mauern und Riegel" have separated them physically, "[ihre] Herzen sind nicht getrennt" (I, 13, 91). Eduard is very aware of his heart's crime; the next morning "die Sonne schien ihm ein Verbrechen zu beleuchten" $(I, 11,85)$. The act that should have united husband and wife succeeded in uniting the unwed couple and separating Eduard from Charlotte, who finds herself alone as she wakes. Eduard later attests to the fact that Otto, the child born to Charlotte and him is "aus einem doppelten Ehebruch erzeugt! es trennt mich von meiner Gattin und meine Gattin von mir, wie es uns hätte verbinden sollen" (II, 13, 224). Though Ottilie and Eduard maintain a physical distance, they become united in mind and spirit, committing a spiritual adultery.

Ottilie's personality changes as a result of the doppelte Ehebruch. The one whose pervading characteristic had been silence, is directly after the event "kindlich heiter," even "offen" (I, 12, 86). The Gehülfe, upon his visit to the estate, attests to Ottilie's changed personality. He finds her to be "erwachsener, gebildeter, und wenn man will, im allgemeinen mitteilender als er sie gekannt hatte" (II, 7, 181). He expresses also "wie er Ottilien in Absicht eines freieren Betragens, einer bequemeren Mitteilung, eines höreren Blicks in die weltlichen Dinge...sehr zu ihrem Vorteil verändert [fand]" (II, 7, 181-82). Not only is she more mature, she has become "klug, scharfsinnig, argwöhnisch... ohne es zu wissen" (I, 17,113). These are not the characteristics of an innocent child, but the traits of one who has approached maturity or has begun the maturing process.

Ottilie's relationship to the other characters changes as a result of her love for Eduard. She immediately draws away from Charlotte and the 
Hauptmann and even spreads dissension between Eduard and Charlotte, although something inside her tells her she shouldn't. "Kaum hatte sie es gesagt, als ihr schon der Geist zuflüsterte, daß sie hätte schweigen sollen" (I, $13,94)$. This first prodding of Ottilie's conscience does not, however, lead her toward a feeling of guilt. Quite the opposite: she continues her normal daily routines quite effectively "getragen durch das Gefühl ihrer Unschuld..." (I, 14, 96) and begins to live for Eduard alone, living in what she deems a "Himmel auf Erden" (I, 14, 96). The justification for her actions comes from Eduard, who convinces her that Charlotte wants a divorce. At the same time however, she feels the need to hide her love for Eduard from the others and to conceal her pain at his departure, deceiving them through many activities. Her actions suggest that she is not fully convinced of her innocence, for if she were completely innocent, there would be no need for deception.

The key to understanding Ottilie's self-presumed yet insecure feeling of innocence comes from a recognition of Ottilie's stage of development. We have seen the narrator describe Ottilie as being "in halbbewußter Jugend" (II, $10,200)$. If "unbewuft" refers to the condition of a child, and "bewußt" to that of an adult, then "halbbewußt" refers to the condition of one in between childhood and adulthood. This state between "unbewußt" and "bewußt" is the adolescent state to which Ottilie belongs. She exists in a world between childhood and adulthood, having a foot in both worlds and therefore not belonging fully to either. True, she changes due to her love for Eduard, yet she obtains these adult characteristics "ohne es zu wissen" (I, 17, 113). The Gehülfe, in his assessment of Ottilie's changed personality, adds that these new qualities were such that they "sich mehr in ihren Handlungen als in ihren 
Worten betätige[n]..." (II, 17, 181). She does not reach the level of awareness necessary to communicate with words more than gesture. She is still unaware of herself and cannot grasp things happening around her. Upon Eduard's departure, "sie verstand es nicht, sie begriff es nicht; aber daß ihr Eduard auf geraume Zeit entrissen war, konnte sie fühlen " $(I, 17,111)$ [my italics], and "peinlich war ihr das Gefühl der Unwissenheit" (I, 17, 116). Ottilie still feels or intuits rather than reasons cognitively, for she is still governed by her feelings rather than by reason. The architect, who has come to restore the chapel, affirms her instinctive goodness, stating that "das Schickliche ist mit [ihr] geboren" (II, 6, 168) [my italics]. Her actions are based upon instinct, not on decisive cognitive reasoning, as if she were not fully aware to make decisions about her own behavior. In training the girls under her care, "Sie folgte ihrem guten Sinne, und ohne sich's ganz deutlich zu machen" (I, 17, 114-15), does she instruct them. Though now possessing adult qualities, Ottilie is unable to use these traits consciously. Instead she continues to operate as before"unbewußt," in a state of adolescence.

Ottilie is able to exist in her adolescent state, remaining unenlightened because her love for Eduard opens her eyes to passion, not to knowledge. Her awareness comes not in the rational but in the emotional realm. It is not a true enlightenment for she is still not fully aware. Conventionally, enlightenment comes as a result of the acquisition of knowledge. Not so with Ottilie; she becomes wise in the realm of love, beginning her ascent to adulthood in the emotional realm, not in the rational. Her love for Eduard does not bring her to a full sense of awareness, and their love is also unconsummated, allowing Ottilie to retain her purity and innocence. She experiences passion in the 
emotional realm only, not in the physical: "sie stehe mit ihm noch in dem innigsten Verhältnis"' (II, 8, 190). She does not reach accountability, for she does not acquire full knowledge. She remains only half-conscious, possessing adult qualities yet not fully aware of herself.

Ottilie's relationship with Eduard is a picture of her adolescent state, being innocent and childlike, yet not without passion. Her attraction for Eduard lies in a fond remembering of the past. "Sie erinnerten sich gern früherer Zeiten, wo sie einander gesehen" $(I, 7,52)$. Her romantic side responds to this link to the past as her childlikeness responds to Eduard's youthful character. "Eduard hatte bei zunehmenden Jahren immer etwas kindliches behalten, das der Jugend Ottiliens besonders zusagte" $(I, 7,52)$. Their musical duet, in which Ottilie at the piano accompanies Eduard's violin playing, resembles a "kindische Handlung" (I, 8, 61), which signifies the nature of their relationship. Yet they themselves are not children, and the whole premise of their love borders on adultery. Their love is not merely innocent affection, yet it is not fully adult. Their relationship is "erotisch aber noch rein und kindlich."53 Eduard reads aloud poems, which attest to such relationships, "solche besonders, in deren Vortrag der Ausdruck einer reinen, doch leidenshaftlichen Liebe zu legen war" $(I, 8,59)$. Eduard and Ottilie's relationship contains these two aspects for it is an adolescent relationship. Their physical love remains guarded and unredeemed, while their emotional attachment grows and thrives. Their love and relationship mirror Ottilie's "halbbewußt" adolescence.

53 Benno von Wiese, Der Mensch in der Dichtung (Düsseldorf: August Bagel Verlag, 1958) 116. 
Symbolic of Ottilie's weakening childhood ties is her willingness to remove the portrait of her father that she wears around her neck and give it to Eduard. In this gesture she distances herself from her childhood. Though this happens before the revelation of their love for each other, to renounce the father in favor of the lover signifies the severing of childhood ties and Ottilie's approach of adulthood. As she removes the portrait, Eduard feels as if a partition between Ottilie and him had fallen: "Ihm war, als wenn ihm ein Stein vom Herzen gefallen wäre, als wenn sich eine Scheidewand zwischen ihm und Ottilien niedergelegt hätte" $(I, 7,56)$. Ottilie's rejection of the father figure and embrace of the lover figure together symbolize her transition into adolescence.

Ottilie's adolescent struggle is typified by an inner agitation from which she physically suffers. The Gehülfe describes her pain as "eine innere, unangenehme, lebhafte Bewegung, der sie widersteht" (I, 5, 42), which manifests itself by an uneven coloring in her cheeks; her left cheek becomes red while her right becomes white, a discoloration symbolizing her adolescent state. While white represents purity and innocence, red represents life, blood (including menstrual), as well as passion, which contrasts childhood innocence. That her left cheek becomes red indicates an awareness on the side of passion and emotion. That her right cheek remains white suggests a maintained purity on the side of reason. So likewise her complaint of headaches on her left side reveals an inner conflict with the emotional side. The emotional side is in conflict with the enlightened world, yet the side in which an individual normally approaches awareness through knowledge remains unaffected, unstained. 
Ottilie's adolescent condition also manifests itself through the pendulum experiment, which the English visitors perform. The experiment, while revealing an affinity to the earth, also reveals Ottilie's inner strife and conflict. At most times she is able to hide her pain and agitation, "denn Ottilie verändert das Gesicht nicht," and never let it occur, "daß sie einmal die Hand nach dem Schlafe zu bewegt hätte" (I, 5, 41-42). Many times "Ottilie schien es nur" [ruhig und heiter zu sein] $(I, 17,114)$ to conceal her inner situation. The pendulum's vigorous movement and the discoloration on her face reveal her internal condition-the inner unrest of an adolescent.

The tableaux vivants, in which Ottilie portrays the Virgin Mary, further reveal Ottilie's inner conflict. She is hesitant to assume such a Holy figure as the Mother of Christ, yet due to her sense of obligation to the architect and her obedience to Charlotte, she concedes. Performing a tableau vivant involved the positioning of actors on a stage in a depiction of famous paintings. Ottilie is able to perform the first tableau vivant well, yet during the second, we see her inner turmoil as she realizes the contradiction of her assumed role and her adolescent state. The first scene is in darkness, with the light projecting only from the Christ child. In contrast, the second scene floods the actors with light, which makes Ottilie uncomfortable, as if the light this time "[ihr] ein Verbrechen zu beleuchten schien" (I, 11, 85). The light exposes her inner agitation in a twofold manner-the light of enlightenment exposes her innocence, while the light of truth exposes her crime of passion. She is not only in conflict with the enlightened world, but now is in conflict with purity and innocence itself. Her adolescence conflicts with both childhood and adulthood. 
The Gehülfe's presence at the illuminated tableau vivant evokes in Ottilie a feeling of inadequacy. The moment she is aware of him she realizes that many things have happened since she had last heard his voice, things she wonders if she ought to confess: "...ihm alles bekennen und gestehen" (II, 6, 172). Which actions require confession except sins? She feels immediate uneasiness, embarrassment and guilt for portraying such a holy figure. Though she does not yet know about the double adultery, she senses her unworthiness in appearing as the Virgin in front of her "treuer Lehrer" (II, 6, 172). The light exposes her in the presence of one who is, for her, the embodiment of truth and knowledge. Again, Ottilie's embarrassment is twofold-the tutor's knowledge contrasts her unawareness; his truth contrasts the deception of her hidden love for Eduard. Her feelings of inadequacy resurface later during Ottilie's conversation with the Gehülfe when he mentions his disapproval of mixing the sensuous and the sacred: "...diese Vermischung des Heiligen zu und mit dem Sinnlichen" (II, 7, 174). He does not say "sinful." He disapproves of the combining of holiness (purity, innocence) and sensuality, criticizing this blend for which the Romantics strove and which Ottilie's adolescence allows her to experience. The Gehülfe's further remarks about the spiritual requirements of education cause Ottilie to reflect upon how much has happened to her during the past year. She admits to having grown due to her experience with Eduard, attributing her learning process to "eine ungeahnete Leidenschaft im vergangenen Jahr" (II, 7, 179). Her own words criticize her experience with adolescence, an expression of her conflicting sympathies. 
Ottilie's love for Eduard provides her an avenue to further develop romantic qualities by allowing her to experience romantic emotions. As mentioned, she describes her experience with Eduard as "eine ungeahnete Leidenschaft" (II, 7, 179). Upon Eduard's departure, the narrator writes, "wir wagen nicht ihren Schmerz, ihre Tränen zu schildern, sie litt unendlich" (I, 17, 111). "Sie fühlte sich auch nur um desto mehr allein" (II, 3, 140), and "fand Raum sich in der Einsamkeit auszuweinen" (II, 10, 201). Ottilie begins to live in a state of reflection and finds solace in the gardens tending to the plants that she and Eduard had planted together. "Doch konnte sie sich von diesen Rabatten und Beeten nicht trennen" (I, 17, 116). Her interest shifts from indoors to outdoors and then from land to water, which sparks in her a longing to travel. "Wie oft eilte das gute Mädchen mit Sonnenaufgang aus dem Hause...ins Freie hinaus.... Auf dem Boden mochte sie nicht verweilen. Sie sprang in den Kahn, und ruderte sich bis mitten in den See: dann zog sie eine Reisebeschreibung hervor, ließ sich von den bewegten Wellen schaukeln" $(I, 17,117)$. She develops envy for travelers, expressing a desire to embark on adventures. This echoes the experience of romantic characters, including Eichendorff's Taugenichts (1826) and Tieck's Franz Sternbald (1798) who imitated the practice of medieval adventures. "Manchmal wenn mich ein neugieriges Verlangen nach solchen abenteuerlichen Dingen anwandelte, habe ich den Reisenden beneidet..." (II, 7, 183). Her curiosity in the exotic grows. She writes in her journal "Es wandelt niemand ungestraft unter Palmen, und die Gesinnungen ändern sich gewiß in einem Lande, wo Elefanten und Tiger zu Hause sind" (II, 7, 183-4). We learn from one of the English visitors that Ottilie becomes quite skilled at rowing and ferrying (II, 
$11,211)$. Such an interest in boats and water remind one of romantic paintings, where water, ships and ships' masts symbolize a transport into the romantic distance- "die weite Ferne," for example Caspar David Friedrich's On the sailing boat, View of a Harbour, and Ship on the Elbe in Mist. Upon the lake Ottilie dreams of Eduard in many far off and exotic places. "[Sie] träumte sich in die Fremde und immer fand sie dort ihren Freund" (I, 17,117). She is sustained by nightly visions of him-“"wundersame nächtliche Erscheinungen zum Trost gegeben, die ihr das Dasein des Geliebten versicherten und ihr eigenes befestigten und belebten" (II, 8, 190). These words remind one of Wackenroder's account of Raffaels Erscheinung from his Herzensergießungen eines kunstliebenden Klosterbruders (1797), in which Raphael's vision of the Madonna revitalizes him ("am andern Morgen sei er wie neugeboren aufgestanden"),54 and of Novalis' Hymnen an die Nacht (1800), "[deren] Thema: Im Bild der Nacht wird die Überwindung des Todes als »hoher Raum« gesucht. In einer Vision gibt die Geliebte Hinweis auf das Jenseits, mit dem auch eine Verbindung durch den heiligen Schlaf möglich wird."55 Because of her love for Eduard, Ottilie has many romantic encounters with the spiritual world that enable her to experience her romantic emotions more fully.

Ottilie sees Eduard before her not only in dreams and visions, but most clearly and distinctly in the romantic realm between sleeping and waking.

\footnotetext{
54 Wilhelm Heinrich Wackenroder, "Herzensergießungen eines kunstliebenden Klosterbruders," Die deutsche Literatur in Text und Darstellung, Romantik I, Band 8, eds. Otto F. Best and Hans-Jürgen Schmitt (Stuttgart: Philipp Reclam jun. GmbH \& Co., 1974) 83.

55 Best and Schmitt, Romantik II, 225.
} 
“Wenn sie sich abends zur Ruhe gelegt, und im süßen Gefühl noch zwischen Schlaf und Wachen schwebte, schien es ihr, als wenn sie einen ganz hellen, doch mild erleuchteten Raum hineinblickte. In diesem sah sie Eduarden ganz deutlich" (II, 8, 190). She experiences his presence in a realm particular to the romantics, who insisted that reality existed somewhere between realities, in the ambiguous state between asleep and awake, between dream and reality. "[Die Romantiker] beschäftigten sich mit der Welt des Traums, mit Somnambulismus, mit Psychosomatik." 56 As characters in romantic novels are not always aware of the boundaries between dream and reality, for example Hyazinth in Novalis' Lehrlinge zu Sais (1798), Bertha in Tieck's Der blonde Eckbert (1797), E. T. A. Hoffmann's Der goldne Topf (1813/14), Ottilie also experiences this phenomenon. The narrator's choice of words links her to this romantic state of uncertainty. "Es schien ihr als wenn sie wäre und nicht wäre" (II, 3, 140). This romantic state of ambiguity correlates to her state of adolescence just as she experiences the suspension between sleeping and waking. She is suspended between the world of children and the world of adults, in adolescence. Key to the romantic state between asleep and awake is the time of day which facilitates this experience. Dawn and twilight enabled one to be closest to the world of dreams and the spiritual. Romantic painter Philipp Otto Runge expressed "wenn die Sonne sinkt und wenn der Mond die Wolken vergoldet, will ich die fliehenden Geister festhalten." 57 Ottilie also "mit Sonnenaufgang" hurries out of the house into the garden where she

\footnotetext{
56 Kleßmann 146.

57 Kleßmann 81.
} 
could experience nature. Her tie to the in-between reality intensifies her spiritual experiences and her discovery of romantic emotions in nature.

Ottilie's spirituality enhances her experience in this romantic inbetween state. Through her monastic asceticism she separates herself from the present world. As the spiritual world is invisible, existing outside of time and space, so Ottilie also, being older in years, yet still childlike and adolescent, belongs to an indefinite time and space. Because of her relationship with Eduard, she withdraws into herself. "Sie ging in sich zurück" (I, 18, 125). The inner reality and perspective was of prime importance to the Romantics. Romantic artist Caspar David Friedrich expressed that, "Der Maler soll nicht bloß malen, was er vor sich sieht, sondern auch, was er in sich sieht." Ottilie's withdrawal into subjectivity provides the spiritual perspective from which she is able to experience the world beyond time and space.

Ottilie's books on travel allow her to draw inward and to lose herself in another world. Habitually she took these travel books with her while she walked in the garden or rowed upon the lake. Many times "sie saß versenkt in ihr Buch, und in sich selbst.... Sie vergaß Zeit und Stunde" (II, 13, 223). Likewise, as Ottilie views the architect's treasures from the Middle Ages, the narrator remarks, "so mußte man sich beinahe selbst fragen: ob man denn wirklich in der neueren Zeit lebe, ob es nicht ein Traum sei, daß man nunmehr in ganz andern Sitten, Gewohnheiten, Lebensweisen und Überzeugungen verweile" (II, 2, 133). Ottilie's connection to the age of innocence removes her to another reality so that her perspective on life comes from the imagined

58 Kleßmann 8. 
splendor of the Middle Ages. She removes herself from contemporary time and space in favor of belonging to the glorious world of her own imagination.

Ottilie's suggestion for the site of the new cottage reveals her "other world" perspective. She maintains that the cottage should be built in such a position that its view exclude the estate and which, sheltered by the woods, "man befände sich...wie in einer andern und neuen Welt" (I, 7, 58). Her wish signifies her affinity to nature, while also revealing her desire that the building be engulfed by nature and exclude any sign of the village that would remind one of civilization and this present age. The site for the new building, completely removed from the civilized world, echoes Ottilie's attempt to withdraw into her own world beyond the present.

Ottilie's spiritual purity and monastic lifestyle enable her to experience the realm beyond the physical and give her a natural tie to the state between dream and reality. Her affinity to the world between the worlds corresponds to her state as an adolescent. She belongs no longer to the world of children, yet is not fully adult, for she has approached enlightenment and awareness "unbewußt." Though she possesses adult characteristics and a conscience, she has not reached accountability, because her awakening is not a full enlightenment in the area of reason. The experience which awakens her passion and changes her character does not lead her on a quest for enlightenment, but rather strengthens her ties to romanticism. She remains in her half-aware adolescence until tragedy strikes with the death of the child Otto. Her final test comes later as a result of Otto's drowning, which brings Ottilie to a state of partial awareness and forces her to make a decision regarding her further development. 


\section{CHAPTER 3}

\section{OTTILIE THE SAINT-TRANSCENDENT AND PERFECTED}

Ottilie's attempted enlightenment comes in several stages, beginning with her deliberate impropriety by kissing Eduard and culminating in her realization of her maturation process and wrongdoing. Ottilie is only able to exist in her adolescent state until her eyes are opened further as a result of her indiscretion upon seeing Eduard again. After a long absence, he returns to the estate and expresses his intentions of wanting to marry her. Ottilie does not resist him, and for the first time, they kiss. Ottilie's resulting turmoil causes the accidental drowning of the child Otto, an effect of her severed ties to nature. According to Ottilie, God uses Otto's tragic death as a tool to open her eyes to her sin. Ottilie becomes aware of her iniquity while she lies semiconscious after the drowning. Because Ottilie's revelation of her offense comes in a half-conscious, death-like sleep, she is able to make a decision to reject full enlightenment and transcend her human frailty by becoming saint-like. As is the case with many romantic characters, when the child becomes enlightened, it cannot return to its prior state of naiveté. It must instead find its way back to purity via a different path. ${ }^{59}$ Through complete renunciation and ultimately through her sacrificial death, by which she atones for her friends' inability to accept her renunciation, Ottilie successfully returns to her state of purity. Her death reunites her with nature and facilitates a pure and everlasting union

59 Heinrich von Kleist, Über das Marionettentheater (Wiesbaden: Insel Verlag, 1959) 9. 
with Eduard. She spurns enlightenment and achieves her romantic goal of everlasting childlike purity.

Ottilie's journey toward enlightenment begins with an experience of human weakness. Her inability to refuse Eduard's amorous pursuit reveals itself in their display of affection through mutual consent of a kiss. During Eduard's absence, Ottilie had accepted that they could not be together, believing herself capable of renouncing him, so long as she did not see hin again. "Sie glaubte sich fähig [Eduard] zu entsagen, sogar ihn niemals wieder zu sehen" (II, 9, 193). Her renunciation is ineffective however. When Eduard surprises her at the lake, she and he are unable to refrain from expressing their love physically. "Sie wechselten zum erstenmal entschiedene freie Küsse" (II, $13,225)$. That which had been solely thought, becomes action. For the first time, Ottilie consciously acts upon her emotions in her open display of love for Eduard. This conscious act against her former resolve to renounce him sets in motion a series of events that causes Ottilie to become aware of her sin.

Ottilie's partial enlightenment continues with the consequences of her actions. The encounter with Eduard leaves her flustered, which causes the accidental drowning of the child, Otto. The kiss, as a means of sexual expression, causes an awareness of sin in Ottilie, just as Adam and Eve's knowledge of nakedness brought an immediate awareness of shame. After the kiss, which leaves Ottilie "verwirrt und bewegt" (II, 13, 225), she believes she sees from afar Charlotte's white dress, a subtle but startling reminder of Ottilie's indiscretion. "Sie sah nach dem Berghause hinüber und glaubte Charlottens weißes Kleid auf dem Altan zu sehen" (II, 13, 225). In an attempt to return to her previous childlike position, she tries to return to Charlotte 
immediately, but in her agitated state of mind, Ottilie's instincts are no longer reliable; in addition, her newly-acquired cognitive thoughts betray her: "Mit Gedanken ist sie schon drüben [to the other side of the lake] wie mit den Augen. Die Bedenklichkeit, mit dem Kinde sich aufs Wasser zu wagen, verschwindet in diesem Drange" (II, 13, 225). Trying to juggle the book she had been reading (a symbol of knowledge) and the child (a symbol of innocence), Ottilie drops both into the water, a sign that the two cannot exist side by side. Ottilie relinquishes her innocence the moment that she acts upon her love for Eduard. As "the wages of sin is death" (Romans 6:23), Ottilie's blatant disregard of Charlotte and the bond of marriage in her open expression of love ultimately culminates with the death of the infant, Otto. The price of awareness is the loss of innocence; the price of innocence is the absence of growth and maturation. Ottilie's innocence dies symbolically with the death of Otto.

Ottilie's partial enlightenment results in her estrangement from nature. Her former affinity to nature changes immediately as a result of her deliberate expression of love. Just as Adam and Eve were banished from the Garden of Eden, having eaten from the tree of the knowledge of good and evil, the acquisition of knowledge in romantic characters brings about a separation from nature. For example, the world speaks no more for Novalis' Hyazinth when he receives knowledge, just as the bird stops singing for Tieck's Bertha when she acquires guilt. ${ }^{60}$ In the same way, nature is now at odds with Ottilie. The lake's water, once a symbol of life and a vehicle of transport into the

${ }^{60}$ Novalis, "Die Lehrlinge zu Sais," and Ludwig Tieck, "Der blonde Eckbert," in Best and Schmitt, Romantik II. 
romantic "weite Ferne," becomes a symbol of death and immovability. "Ohne Bewegung liegt das Kind in ihren Armen, ohne Bewegung steht der Kahn auf der Wasserfläche" (II, 13, 226). Having lost the rudder in the middle of the lake, Ottilie cannot reach the shore or even establish a direction. Mirroring Ottilie's condition, "Die Natur scheint selber verwirrt und bewegt zu sein, mit sich selbst in Widerstreit zu legen."61 Reciprocally, nature now betrays the betrayer. Ottilie, having formerly betrayed Charlotte in her heart and now openly with a kiss, finds herself betrayed by the elements, which earlier provided solace for her. The words "Das Wasser ist ein freundliches Element für den, der damit bekannt ist und es zu behandeln weiß" (II, 10, 208) no longer apply to Ottilie, "die schöne Schifferin (II, 11, 211)" who was used to taking the "Stelle des Fährmanns" (II, 11, 211) in the boat. Mysteriously she loses her skill upon the water when the accident occurs. Her help does not come until, realizing her tragic circumstance, she lifts her eyes toward heaven. "Mit feuchtem Blick sieht sie empor und ruft Hülfe von daher, wo ein zartes Herz die größte Fülle zu finden hofft, wenn es überall mangelt" (II, 13, 227). God intervenes, sending a breeze that guides her to shore. Her tie to nature is no longer automatic but requires divine intervention.

Ottilie's attempted enlightenment reveals the fallacy of her former way of living. While she rests half-conscious, exhausted after the accident, the revelation of her sin occurs, making her aware of the maturing process that had begun in her. Ottilie claims "Auf eine schreckliche Weise hat Gott mir die Augen geöffnet, in welchem Verbrechen ich befangen bin" (II, 15, 232). The

61 Schelling-Schär 126. 
drowning of the child is God's tool to open her eyes and make her aware of the sin in which she is trapped-her love for Eduard, Charlotte's husband. Ottilie admits "Ich bin aus meiner Bahn geschritten, ich habe meine Gesetze gebrochen und das Gefühl derselben verloren" (II, 14, 232). This "Bahn" was her former code of living that she had set up for herself. "Ich machte mir nach meinen beschränkten Einsichten hierüber Gesetze; nach diesen habe ich lange gelebt" (II, 14, 232). Her limited insight in forming this old standard was due to her childlike perspective. Her Gesetze by which she had lived, included her former monasticism and withdrawal from the world as an attempt to maintain her childlike innocence and to fulfill her destiny "als eine arme Waise in der Welt geblieben zu sein" (II, 14, 231). She realizes that she has not been successful in remaining separate from the enlightened world, and that she has gained awareness as a result of her sin and its consequences. She no longer has the privilege to turn her eyes away from that which she did not wish to know (II, 10, 200), because she has become aware of her sin.

Comparing Ottilie's circumstance with Adam and Eve's fall from grace, Ottilie's test of enlightenment is significantly different from the test in the Garden of Eden. Adam and Eve, aware of their test and its consequences, chose the wrong and were therefore accountable. Ottilie sins in her innocence, but once she is made aware of this sin, she instantaneously refuses to continue in it. Earlier Eduard had wondered "wenn sie mich liebt, wie ich glaube, wie ich weiß, warum entschließt sie sich nicht, warum wagt sie es nicht, zu fliehen und sich in meine Arme zu werfen" (I, 18, 119)? At that point, Ottilie was not able to make a conscious decision. Instinctively she knew it was not right to go to him. Cognitively now she chooses not to go to him. She renounces Eduard, 
declaring "Eduard werde ich nie" (II, 14, 232). According to biblical tradition, the age of awareness comes when a child "knows enough to reject the wrong and choose the right" (Isaiah 7:16). In her innocence, Ottilie had done the right thing instinctively; in her awareness she does the right thing deliberately, passing her test of obedience at her acquisition of knowledge in her "halbbewußt" state.

Ottilie's enlightenment is never fully realized. Instead, she rejects and transcends it. As Ottilie lies in semi-conscious exhaustion, Charlotte remarks that she fears "wenn [Ottilie] aus ihrem halben Totenschlafe zum Bewußtsein erwacht" (II, 14, 230). Charlotte realizes that Ottilie's innocence is threatened by awareness. The revelation of her crime makes Ottilie realize her mistake. She sets herself on a course for salvation while in her "halben Totenschlaf." She never fully awakens, but rather refuses the snare of enlightenment in favor of ascending to a state of spiritual piety. In this "halbbewußt" state she comes to the crossroads between childhood and adulthood and refuses to take any steps forward to reach beyond her current condition. Perceiving enlightenment as a jaded prize, she shrinks from the opportunity to grow up, choosing instead to remain in her childlike state. Ottilie rejects Kant's formula for enlightenment, refusing to leave her state of "selbstverschuldeten Unmündigkeit." She remains in her self-caused immaturity and never awakens from her "halben Totenschlaf," refusing to leave her "halbbewußter Jugend." Compared to Belisarius, the blind innocent beggar, known because of Van Dyck's painting "Belisar" of which Luciane performs a tableau vivant, Ottilie is also blind in her refusal of enlightenment. "Das Innernleben, das Ottilie nach dem Heimkehr bis zu ihrem Tode lebt, bleibt im Dunkel... [sie 
geht]...den dunklen Weg der Entsagung bewußt schweigend zu Ende...."62

Ottilie gains awareness of her iniquity, but she refuses enlightenment and so chooses to remain in darkness. She transcends her own existence, proceeding from innocent child to saint. Her transcendence releases her from her human frailty and enables her to reach a state of sinless perfection. This transcendence, however, comes at a price.

Ottilie's rejection of enlightenment manifests itself in her refusal of the contents of the red suitcase, which Eduard gives her as a birthday gift. Red symbolizes passion and maturity, while a suitcase symbolizes travel into the unknown. Though willing to open the case and view its elegant contents, Ottilie "wagte es nicht auseinander zu nehmen, ja kaum zu lüften wagte.... Es war aber alles so kostbar und fremd, daß sie sich's in Gedanken nicht zuzueignen getraute" $(I, 15,105)$. Her unwillingness to accept the case's contents as her own correlates to Ottilie's position in life. She opens the lid, as it were, to the process of becoming an adult, observes what that entails, but does not embark on the journey that would speed her on her way to adulthood. In the same manner, she "rückte sich [Eduard] näher, um ins Buch zu sehen..." (I, 8, 60), as if only to peer into enlightenment, to remain observant, but not to take part, while nevertheless moving closer to becoming enlightened. At night, Ottilie habitually kneels before the red case, realizing that therein lies the answer to being reconciled with Eduard; in order to be one with him, she must leave her innocence behind. She is, however, incapable of this decision and, in a display that resembles a refusal of a Pandora's box, she

62 Oskar Walzel, "Goethes Wahlverwandtschaften in Rahmen ihrer Zeit," Goethe Jahrbuch 27 (1906): 22. 
leaves the case's contents untouched until just before her death, rejecting the process of enlightenment. Later, placed next to Ottilie's sarcophagus, the red case stands forever as a reminder of Ottilie's inability to grow up.

Ottilie's newly gained state of awareness is irreversible, but may be overcome. Once even partial enlightenment is achieved, an individual cannot return to a state of complete unawareness. "Seitdem wir von dem Baum der Erkenntnis gegessen haben.... Doch das Paradies ist verriegelt und der Cherub hinter uns; wir müssen die Reise um die Welt machen und sehen, ob es vielleicht von hinten irgendwo wieder offen ist." 63 Ottilie cannot return to her previous state of innocence without undergoing a journey that will allow her to return to purity through a different path. Like the young woman in the Novella, Die wunderlichen Nachbarkinder (told by the Englishman in part II), Ottilie "war verwandelt, doppelt verwandelt, vorwärts und rückwärts, wie man es nehmen will" (II, 10, 206). Because of her attempted enlightenment, Ottilie is changed for the past (rückwärts) in that she will never regain a state of total unawareness that had characterized her innocent and childlike condition. She is changed for the future (vorwärts) because she cannot continue in her old way but must now set herself on a course to regain a state of purity. Her awareness makes it impossible for her character to remain static. In her half conscious sleep, she comes to the awareness that she has "aus (ihr)er Bahn geschritten." She then makes the decision to put herself on a new course of action. "Wie damals habe ich auch diesmal in meinem halben Totenschlaf mir meine neue Bahn vorgezeichnet" (II, 14, 232). She now vows to work with all

63 Von Kleist 9. 
her heart-no longer in self denial, but with the satisfaction that comes from hard work and the peace that comes from complete renunciation.

Ottilie seeks to achieve perfection through piety, by means of complete renunciation of her affections for Eduard. This desire for renunciation sets her free from her vow of servitude and changes her character.

"Sie war von ihrer frühen Einschränkung, von ihrer Dienstbarkeit entbunden. Durch ihre Reue, durch ihren Entschluß, fühlte sie sich auch befreit von der Last jenes Vergehens, jenes Mißgeschicks. Sie bedurfte keiner Gewalt mehr über sich selbst; sie hatte sich in der Tiefe ihres Herzens nur unter der Bedingung des völligen Entsagens verziehen, und diese Bedingung war für alle Zukunft unerläßlich" (II, $15,234)$.

Through renunciation and hard work, Ottilie seeks to atone for the laws she has broken. "Ich will es büßen" (II, 14, 232). In her naiveté she sins; in her halfconscious awareness she renounces the object of her sin; and by her piety she atones for her sin. Her attempt to return to the purity of innocence requires a striving to achieve a state of sinless perfection through renunciation.

The enlightenment experience changes Ottilie's relationship to the other characters. When she finally awakens "denn sogleich richtete Ottilie sich auf, ihre Freundin mit großen Augen anblickend. Erst erhob sie sich von dem Schoße, dann von der Erde und stand vor Charlotten" (II, 14, 231), an act which depicts her entire development of birth ("von dem Schoße") and rebirth ("von der Erde" - resembling a resurrection), signifying a simultaneous salvation experience with her rejection of enlightenment. In one moment she is convicted of sin and sanctified because of her instantaneous response to renounce her sin. The child who once cowered at Charlotte's feet now stands calmly before her with eyes wide open. She is now Charlotte's equal, an adult, 
even her superior. "It is as though by revealing the laws of her moral existence, by condemning the agreement to a divorce, she has become adult, Charlotte's equal, if not her superior."64 Eduard confirms that "[Ottilie] hat sich über mich weggehoben" (II, 17, 247). Ottilie's reaction to Eduard at the inn reveals a further change in her character. She no longer shows signs of suffering from an inner agitation. Her response upon seeing him is calm and controlled, in contrast to her earlier purely emotional response at the lake. "Sie sah ihn ruhig und ernsthaft an, ohne vor- oder zurückzugehen" (II, 16, 243). Referring to the encounter at the inn, Ottilie offers an explanation for her controlled behavior. "Nach Gefühl und Gewissen des Augenblicks schwieg ich" (II, 17, 247). Her emotions and her cognition, once in conflict, now work in unison. Ottilie's renunciation sets at rest her adolescent agitation and changes her social position within the group of characters due to her state of spiritual elevation.

Ottilie foreshadows her own sainthood, assuming roles that identify her with the Virgin Mary. She holds the child Otto at his christening, revealing that she "is the virginal mother of Otto." 65 Her portrayal of the Virgin in the "only religious tableau vivant" foreshadows her future sinless state. 66 The architect, convinced of Ottilie's sainthood, 'hatte [Ottilie] in seinem Sinne zur Mutter Gottes erhoben" (II, 6, 170). Likewise, the saints in the frescos that the architect had painted in the chapel declare her sainthood. "Auch die

\footnotetext{
${ }^{64}$ Barnes 152.

65 Barnes 127.

66 Lillyman, Tableau Vivant, 353.
} 
Gesichter, welche dem Architekten zu malen allein überlassen war, zeigten nach und nach eine ganz besondere Eigenschaft: sie fingen sämtlich an, Ottilien zu gleichen...so daß es schien als wenn Ottilie selbst aus den himmlischen Räumen heruntersähe" (II, 3, 138). ${ }^{67}$ As is the custom for painters to select one perfect face and use that as their prototype, the architect selects Ottilie as his. "She rises above the level of the individual to an archetype." 68 Ottilie herself expresses in her journal "Alles Volkommene in seiner Art muß über seine Art hinausgehen, es muß etwas anderes Unvergleichbares werden" (II, 9, 194). The architect's view of Ottilie as saint and her identification with the Virgin Mary foreshadows Ottilie's later ascension to sainthood.

Ottilie's position of transcendence reflects her transition from naive child to spiritual mentor. Having symbolically ascended to the status of saint, she decides to return to the boarding school, to fulfill her destiny as a moral teacher. She informs Charlotte that she will instruct others in light of her newly gained insight into the matters of life brought about by her tragic experience. She desires to fulfill her destiny, not as a teacher of knowledge that comes from formal, academic instruction, but as a teacher of the wisdom that comes from life experience. By this she identifies herself with saints who

67 Ottilie's resemblance of the saints in the chapel reminds one of Robert Schumann's song cycle "Dichterliebe" in which a stanza he took from Heine reads as follows: "Im Dom da steht ein Bildnis aus goldenem Leder gemalt; In meines Lebens Wildnis hat's freundlich hinein gestrahlt, Es schweben Blumen und Englein um unsre Liebe Frau; Die Augen, die Lippen, die Lippen, die Wänglein, Die gleichen der Liebsten genau."

68 Paul Leu, "Time and Transcendence in Goethe's Wahlverwandtschaften," Monatshefte 60 (1968): 375 . 
sought to redeem others through their teaching. ${ }^{69}$ As she reveals to Charlotte her plan, she begins to speak in the style of the maxims she had previously written down, stating:

"Der Glückliche ist nicht geeignet Glücklichen vorzustehen: es liegt in der menschlichen Natur, immer mehr von sich und von andern zu fordern, je mehr man empfangen hat. Nur der Unglückliche, der sich erholt, weiß für sich und andere das Gefühl zu nähren, daß auch ein mäßiges Gute mit Entzücken genossen werden soll"' (II, 15, 236).

She realizes that she has ascended to a superior position, having learned from her tragic circumstance, and that it is her duty to then reveal her insight to others. Ottilie's understanding of and triumph over her final test of enlightenment allows her to claim this superiority and become a spiritual mentor.

Though Ottilie ascends to a superior spiritual state, her attempts at renunciation are futile because of the carnal state of the others. Though she is able to renounce Eduard completely, he is unable to renounce her. Against her wishes he pursues her relentlessly, begging her to marry him. She admits to “ein feindseliger Dämon [which some denote as Eduard's love], der Macht über mich gewonnen, scheint mich von außen zu hindern" (II, 17, 246)..$^{70}$ She is swayed no longer by agitation from within but from without. The attempt to live together as before proves futile, foreshadowed by Charlotte's unheeded warning: "Laß dich nicht zufällig, nicht durch Überraschung, in die vorigen Verhältnisse wieder hineinziehen: dann gibt es erst einen Zwiespalt im Gemüt, der unerträglich ist" (II, 15, 238). Ottilie realizes that Eduard is not

${ }^{69}$ Lillyman, Affinity, 55.

70 Lillyman, Tableau Vivant, 356. 
able to give her up, nor are the characters able to return to the conditions of the past.

Realizing the inadequacy of the others, Ottilie makes a decision about her next step. She must now become an atoning sacrifice for Eduard by removing the cause of his sin and the object of his temptation-herself. "Renunciation becomes atonement" as "Ottilie takes the guilt of all upon her and expiates it in their stead."71 She expresses her aim at substitutionary atonement in her final request of Eduard: "Versprich mir zu leben" (II, 18, 254). Her death is meant to give life to him. She had earlier determined "that her love, in order to be perfect, must become completely unselfish."72 "Ihre Liebe, um sich zu vollenden, völlig uneigennützig werden müsse" (II, 9, 193). Since "Greater love has no one than this, that he lay down his life for his friends" (John 15:13), Ottilie gives her life in exchange for Eduard's as an expression of supreme and perfect love. Ottilie sacrifices herself so that Charlotte's and Eduard's marriage may continue unhindered here on earth.

Ottilie's sacrifice is meant to reconcile Charlotte and Eduard. Earlier, she had declared this her role by pressing Charlotte's and Eduard's hands together. "Mit Eifer und Gewalt faßt sie die Hände beider Ehegatten, drückt sie zusammen..." (II, 17, 244). This act of mediation fulfills the double prophecy of the old clergyman at Otto's christening. His declaration of Otto as the "Heiland dieses Hauses" (II, 8, 189) is fulfilled in Ottilie who identifies

\footnotetext{
71 Atkins 14 and Dickson 181 are two examples of the tendency among scholars to view Ottilie's death as an atonement. Christian interpretation of Ottilie and her death comprise a vast majority of interpretations.

72 Barnes 156.
} 
closely with the child. The decorating of the chapel also depicts her role as mediator by showing that Ottilie is effective in uniting heaven and earth. "So wurden noch Blumen und Fruchtgehänge beschlossen, welche Himmel und Erde gleichsam zusammenknüpfen sollten. Hier war nun Ottilie ganz in ihrem Felde" (II, 3, 138). Uniting heaven and earth becomes Ottilie's ultimate and final accomplishment as he succeeds in reconciling Eduard to God by atoning for his sin. When Eduard dies, he is saved through her. "Und wie er in Gedanken an die Heilige [Ottilie] eingeschlafen war, so konnte man wohl ihn selig nennen" (II, 18, 261). Ottilie's death as saint fulfills her role as mediator and reconciler.

Ottilie's acts of mediation, reconciliation through her substitutionary atonement closely identify with Christ's work on the cross. Likewise, the other characters bear witness to her Christlikeness. For the architect, Ottilie becomes his sustainer in life. "Er hatte ohnehin wenig Bedürfnisse, und Ottiliens Gegenwart schien ihm statt alles Labsals zu sein; indem er um ihretwillen arbeitete, war es als wenn er keines Schlafs, in dem er sich um sie beschäftigte, keiner Speise bedürfte" (II, 6, 170). This statement reminds one of the words of Jesus to the woman at the well: "whoever drinks the water I give him will never thirst" (John 4:14). The architect later admits "es ward ihm so schwer, dieses Haus, diese Famile zu verlassen, ja es schien ihm unmöglich von Ottiliens Augen zu scheiden, von deren ruhig freundlich gewogenen Blicken er die letzte Zeit fast ganz allein gelebt hatte" (II, 6, 169). Ottilie's very presence is life for him. Nanny's exuberance and insistence that Ottilie had risen and forgiven her echo the response of the disciples at their master's resurrection. After Ottilie dies, people bring their sick to her crypt to receive 
healing. Ottilie's role as mediator, reconciler and forgiver, shows her to be a Christ type. ${ }^{73}$

As a type of Christ, Ottilie identifies with the innocent, falsely accused. The architect likens Ottilie to Van Dyck's Belisarius, the innocent blind man, wrongly condemned, of which Luciane and the architect had earlier performed a tableau vivant. ${ }^{74}$ Mittler, the self-appointed counselor of marital difficulties, wrongly condemns Ottilie with his words from the 7th commandment of Moses "du sollst nicht ehebrechen" (II, 18, 253). Eduard, not Ottilie, is guilty of breaking this commandment. Where Ottilie was innocently at fault lies in Mittler's next statement: "Du sollst Ehrfurcht haben von der ehelichen Verbindung" (II, 18, 253). Mittler expounds:

"wo du Gatten siehst die sich lieben, sollst du dich darüber freuen und teil daran nehmen wie an dem Glück eines heitern Tages. Sollte sich irgend in ihrem Verhältnis etwas trüben, so sollst du suchen es aufzuklären: du solltst suchen sie zu begütigen, sie zu besänftigen, ihnen ihre wechselseitigen Vorteile deutlich zu machen, und mit schöner Uneigennützigkeit das Wohl der andern fördern, indem du ihnen fühlbar machst, was für ein Glück aus jeder Pflicht und besonders aus dieser entspringt, welche Mann und Weib unauflöslich verbindet" (II, 18, 253).

Though Ottilie has renounced Eduard, she sees that the others still condemn her for her mistake. Realizing this, she takes this admonition as her duty and

73 “Type, Typology," Evangelical Dictionary of Theology, ed. Walter A. Elwell (Grand Rapids: Baker Book House, 1984) 1117-1118. "From the Greek word for form or pattern, which in biblical times denoted both the original model or prototype and the copy that resulted. In the NT the latter was labeled the antitype, [used to denote] the correspondence between...two figures like Adam and Christ...biblical typology involves an analogical correspondence in which earlier events, persons, and places in salvation history become patterns by which later events and the like are interpreted."

74 Lillyman, Affinity, 58. 
seeks to accomplish them through her death, by removing herself as the obstacle to Eduard and Charlotte's happy union. In addition to Mittler's condemning statements, Nanny, Ottilie's personal maid, also inadvertently condemns her mistress. Nanny's proclamation that the dress Ottilie had made was a wedding dress: “...das ist ein Brautschmuck ganz Ihrer wert" (II, 18, 253) condemns Ottilie for the last time. Upon hearing Nanny's words, Ottilie collapses. Nanny admits that Ottilie had not been eating, which reveals that Ottilie has been consciously seeking her death for some time. Earlier, at Eduard's frantic episode at the inn, Ottilie realizes that he is not able to renounce her and that her attempt at renunciation cannot succeed because of his pitiful state. At this point her vow of silence and refusal of food begins. Ottilie extols Charlotte and Eduard in her letter "Dringt nicht in mich, daß ich reden, daß ich mehr Speise und Trank genießen soll, als ich höchstens bedarf" (II, 17, 247). Her realization of the others' inadequacy to accept her renunciation causes her to begin the process of starvation that will allow her to atone for them. Mittler's and Nanny's condemnations are just final reminders of their inadequacy. Ottilie dies innocently condemned as were Belisarius and Christ.

Ottilie's death not only accomplishes her work as savior, it also satisfies her romantic desires by allowing her to pass from life to death, from child to perfected saint, without growing up. "Der fortdauernd schöne, mehr schlafals totenähnliche Zustand Ottiliens" (II, 18, 259) asserts that her death is not an end but an avenue by which she can continue on forever in a continuing romantic half dream-like state. She is buried in "ein starkes eichenes Behältnis (an oak being a romantic symbol of nature's magic)...zu ihrer Häupten der 
Sarg des Kindes, zu ihren Füßen das Köfferchen" (II, 18, 257). That she should lie forever between the symbol of innocence (the child) and the symbol of awareness (the red traveling case) is a living picture of her never-ending existence in "halbbewußter Jugend." She dies successfully joining these two states of being in her own person, aware and perfected, yet pure, never growing up. She remains the ever-present portrayal of the romantic ideal of the child.

Ottilie's oak shrine forever unites her with nature, displaying her regained affinity. Because of her re-acquired relationship with nature, which Ottilie's return to purity reestablishes, nature foreshadows Ottilie's death. Earlier, in the garden, Ottilie "sich besonders bei den Astern aufgehalten, die gerade dieses Jahr in unmäßiger Menge blühten" (II, 17, 250). Upon seeing nature's anticipation of death, Ottilie unpacks the suitcase for the first time to make for herself a dress out of its contents. "After we learn that nature has bedecked herself with asters of death, our heroine unpacks the trunk for the first time; she uses only what is needed for the bridal gown that takes the place of her shroud."75 Her destiny to die began with Eduard, who "marked her birth with the planting of planes and poplar tress; poplar trees for lining the avenue of approach and plane trees for shade are commonly associated with European graveyards." 76 Ottilie confirms this connection in her diary, writing "mit den Bäumen...haben wir ein wahres Verhältnis" (II, 7, 183). Later, nature mourns Ottilie's death through the asters in the wreath on her head,

\footnotetext{
75 Samuel J. Macey, "On the Relationship between Eduard and Ottilie in Goethe's Wahlverwandtschaften," Seminar VII.2 (1974): 82.

76 Bächtold-Staubli, Aberglauben, as quoted in Macey 82.
} 
"die wie traurige Gestirne ahnungsvoll glänzten" (II, 18, 255). The narrator reveals that "Die Bahre, die Kirche, die Kapelle zu schmücken wurden alle Gärten ihres Schmucks beraubt. Sie lagen verödet als wenn bereits der Winter alle Freude aus den Beeten weggetilgt hätte" (II, 18, 255). The whole garden is stripped of its splendor in a display of grief. This absence of beauty in the garden reflects Ottilie's absence from the world. Her oak shrine forever unites her with nature and stands as a manifestation of Ottilie's continuing romantic affinity to nature.

Ottilie's death unites her to Eduard in a state of everlasting purity. As a romantic, Ottilie's love for Eduard cannot be realized in the temporal; it can only be satisfied in the eternal, in their "reunion after death"77 of which the narrator makes mention: "So ruhen die Liebenden nebeneinander.... ..., und welch ein freundlicher Augenblick wird es sein, wenn sie dereinst wieder zusammen erwachen" (II, 18, 261). Only eternity can provide the two with the never-ending state of love that was so desirable for the Romantics. Her love for Eduard is a romantic love for it is "unerfüllbar."78 The fulfillment of their love can only come in the Everlasting. Thus "ihre Liebessehnsucht scheint fast in Todessehnsucht."79 Throughout the novel Ottilie displays an unusual curiosity about death and a concern, especially in her diary entries, for the eternal. She remarks "Wir blicken so gern in die Zukunft" (II, 4, 150) and questions "Ist denn alles was wir tun für die Ewigkeit getan" (II, 3, 136)? At

\footnotetext{
77 Barnes 137.
}

78 Von Wiese 116.

79 Stöcklein 26. 
the Clergyman's death, "Ottilie allein betrachtete den Eingeschlummerten, der noch immer seine freundlich einnehmende Miene behalten hatte, mit einer Art Neid. Das Leben ihrer Seele war getötet, warum sollte der Körper noch erhalten werden" (II, 9, 190). Realizing that her love for Eduard could not express itself in this world, she desires to ascend to the world beyond in order to at last find relief and fulfillment of her love. "Sie entsagt nicht der Liebe, sondern der Erfüllung der Liebe in diesem Leben." 80 Ottilie's death brings everlasting union with Eduard, the never-ending fulfillment of her romantic desires.

Ottilie's death is necessary in order for her to return to her romantic portrayal of the innocent child. Having experienced partial enlightenment, Ottilie cannot remain unaware, and so must seek perfection by transcending her humanity to a state of sinless perfection. She is able to reach this state because her attainment of awareness comes in her half-conscious dream-like state, in which she makes the decision not to fully awaken to enlightenment but to exchange her innocence for a state of purity achievable through complete renunciation. Unable to accomplish this state of perfection on earth, due to the inadequacy of the others, Ottilie atones for them and dies in her perfected state. In death, Ottilie fulfills her aim as a romantic, achieving unending childhood innocence in eternity.

80 Von Wiese 127. 


\section{CONCLUSIONS}

Ottilie manifests the qualities of Romanticism through her portrayal of the child in the age of innocence whose pre-enlightened perspective puts her in conflict with the enlightened world. This conflict forces her to seek separation from the present and to withdraw into the romantic past, establishing an affinity to the Middle Ages through a monastic lifestyle. Unable to remain completely unaffected by her enlightened environment, she becomes partially aware, exhibiting characteristics of an adolescent and displaying a connection to the romantic state of "inbetweenness," a halfconscious awareness, neither asleep nor awake, neither child nor adult. Ottilie answers her moment of decision with the resolution to refuse further enlightenment and to deny herself maturation. Being unable to return to a state of innocence, due to her gained awareness, she seeks ascension to a state of perfection, in which she can die in a state of childlike purity and atone for the sins of others. Her act of atonement enables her to be united with Eduard in death forever, where their love can never end. Ottilie, both unable and unwilling to leave her innocence, shows herself to be a true Romantic, by her refusal to mature and her willingness to sacrifice herself as the ultimate expression of the romantic withdrawal from the enlightened world.

Because Ottilie portrays the romantic ideal of childhood, she seems to be Goethe's vehicle to express his views on Romanticism. " 'Romantische Mitteilungen' nennt [Goethe] sein werdendes Werk." 81 Determination of what

\footnotetext{
81 Stöcklein 65.
} 
those messages are hinges upon an explanation of Ottilie's death, which is the key to interpreting Goethe's intent for Ottilie. Two possibilities for explanation of her character exist: she is either Goethe's commendation or condemnation of Romanticism. Goethe either condemns Romanticism by allowing Ottilie to die so young without having developed, or he commends Romanticism by allowing Ottilie to achieve a state of eternal perfection without being spoiled by enlightenment. Ottilie's death is either a triumph or a tragedy depending on which view the reader espouses.

For the romantic, Ottilie's life and death are a triumph. She succeeds in passing from this world, having proceeded from an innocent child to saint into everlasting life, unscathed by the corruption of the enlightenment. She spurns enlightenment by rising above it to a perfected state of being, regaining her purity, achieving the goal of the Romantic. She becomes the immer Werdende. Eduard's and her love will continue on in the purity and immutability of the eternal. Her success in evading enlightenment would appear to reveal Goethe's approval of the romantic desire to maintain ties to childhood innocence. That the romantic ideal succeeds, expresses triumph. "Die Wahlverwandtschaften is a sympathetic critique of Romanticism" 82 for the novel presents Ottilie as a mysterious but amiable character. Goethe himself confessed to being in love with Ottilie. "[Goethe] sprach von seinem Verhältnis zu Ottilie, wie er sie Lieb gehabt." 83 Ottilie's displacement in the

82 Lillyman, Tableau Vivant, 366.

83 Johann Wolfgang von Goethe, Die Wahlverwandtschaften (München: Deutscher Taschenbuch Verlag GmbH \& C. KG, 1991) 263. 
world and her innocence cause the reader to empathize with her plight. Ottilie cannot become enlightened, for she would then lose her innocent charm.

For the non-romantic, Ottilie's death is a tragedy, for she never does fully reach true enlightenment and awareness. Because she refuses these, she is unable to grow and mature. "The romantic tendency toward the past; for Goethe a failure of growth [is] reflected in Ottilie's failure to develop to her full potential." 84 Statements such as "man müßte darüber verzweifeln, wenn nicht überhaupt in der Welt so weniges eine gehoffte Folge zeigte. Kinder halten nicht was sie versprechen; junge Leute sehr selten, und wenn sie Wort halten, hält es ihnen die Welt nicht" (I, 10,75) by the Gehülfe, or "Wer in einem gewissen Alter frühere Jugendwünsche und Hoffnungen realisieren will, betrügt sich immer" (II, 12, 217) from Eduard, reveal a disapproval for the romantic regression to childhood. Goethe admits that Ottilie "ihn Unglück gemacht." 85 That one so lovely should die so young without a chance for further development is a tragedy. Stöcklein insists that "Das Werk [war] in einem Agon mit der Romantik unternommen...." 86 From an enlightened perspective, to refuse growth is the ultimate tragedy.

A possible compromise is to see Ottilie as simply a picture of a principle, which Charlotte and the Gehülfe discuss in part II, at the beginning of chapter 8 , iterating that each generation will forsake the ideas of the former and espouse the views of the generation once removed. The passing of one

\footnotetext{
84 Lillyman, Tableau Vivant, 365.
}

85 Johann Wolfgang von Goethe, Die Wahlverwandtschaften (München: Deutscher Taschenbuch Verlag GmbH \& C. KG, 1991) 263.

86 Stöcklein 67. 
generation is necessary in order for the next generation to come and prosper. Objectively one realizes that in order for maturity to come, childhood must die. "When I was a child, I talked like a child, I thought like a child, I reasoned like a child. When I became a man, I put childish ways behind me" (I Cor. 13:11). The cost of enlightenment is the loss of innocence. The death of the clergyman (Catholicism), the death of Otto (innocence), and the death of Ottilie (naiveté) signify the romantic ideals that must be sacrificed in order for the Enlightenment to come and thrive. Progress comes at a price. Ottilie's life and death then are a picture of the changing times, supporting Goethe's claim that Die Wahlverwandtschaften "sei eigentlich nur für die Zeit gemacht." 87 Ottilie's death is inevitable in a world saturated with enlightenment.

Whether Ottilie's life and death are meant to express triumph or tragedy is unclear. What is clear is Ottilie's refusal of enlightenment that reflects the Romantics' rejection of the Enlightenment. Ottilie's life and death portray the romantic ideal of the child. Her character embodies the romantic idealization of childhood as a means of withdrawal from the enlightened world. Through her portrayal of innocent childlikeness, her adolescent conflict with enlightenment, and her final rejection of the enlightenment process she succeeds in maintaining her romantic childlikeness. Ottilie's representation of the child figure is an effective portrayal of the romantic ideal of childlike innocence.

87 Stöcklein 65. 


\section{BIBLIOGRAPHY}

Atkins, Stuart. "Die Wahlverwandtschaften: Novel of German Classicism." GQ 53 (1980): 1-45.

Barnes, H. G. Goethe's Die Wahlverwandtschaften, a Literary Interpretation.

Oxford: Clarendon Press, 1967.

Best, Otto F. and Hans-Jürgen Schmitt, eds. Die deutsche Literatur in Text und Darstellung: Romantik I. Band 8. Stuttgart: Philipp Reclam jun. GmbH \& Co., 1974.

Best, Otto F. and Hans-Jürgen Schmitt, eds. Die deutsche Literatur in Text und Darstellung: Romantik II. Band 9. Stuttgart: Philipp Reclam jun. GmbH \& Co., 1974.

Blackall, Eric. Goethe and the Novel. Ithaca: Cornell University Press, 1976.

Dickson, Keith. "The Temporal Structure of Die Wahlverwandtschaften." GR (1966): 170-185.

Drake, Patricia. “Ottilie revisited." GQ 26 (1953): 248-257.

Elwell, Walter A. ed. Evangelical Dictionary of Theology. Grand Rapids: Baker Book House, 1984.

Feuerlicht, Ignace. "Der Erzähler und das 'Tagebuch' in Goethes Wahlverwandtschaften." Goethe-Jahrbuch 103 (1986): 316-343.

Gelley, Alexander. "Ottilie and Symbolic Representation in Die Wahlverwandtschaften." Orbis Litterarum 42 (1987): 248-261.

Goethe, Johann Wolfgang von. Die Wahlverwandtschaften. München: Deutscher Taschenbuch Verlag GmbH \& Co KG, 1991.

---. Die Wahlverwandtschaften. Stuttgart: Philipp Reclam Jun., 1956.

Hatfield, Henry. "Towards the Interpretation of Die Wahlverwandtschaften." GR 23 (1948): 104-114. 
Kleist, Heinrich von. Über das Marionettentheater. Wiesbaden: Insel Verlag, 1959.

Kleßmann, Eckart. Die deutsche Romantik. Köln: DuMont Buchverlag, 1979.

Leu, Paul. "Time and Transcendence in Goethe's Wahlverwandtschaften." Monatshefte 60 (1968): 368-378.

Lillyman, William J. "Affinity, Innocence and Tragedy: the Narrator and Ottilie in Goethe's Die Wahlverwandtschaften." GQ 53 (1980): 46-63.

Lillyman, William J. "Monasticism, Tableau Vivant and Romanticism: Ottilie in Goethe's Die Wahlverwandtschaften." JEGP 81 (1982): 347-366.

Macey, Samuel J. "On the Relationship between Eduard and Ottilie in Goethe's Wahlverwandtschaften." Seminar VII.2 (1971): 79-84.

Mann, Thomas. "Zu Goethes Wahlverwandtschaften." Gesammelte Werke. Band IX. Frankfurt am Main: S. Fischer Verlag, 1960. 174-186.

Mayer, Elizabeth, and Louise Bogan, trans. Elective Affinities. By Johann Wolfgang von Goethe. Westport, CT: Greenwood Press, 1976.

Nolan, Erika. "Das Wahre Kind der Natur? Zur Gestalt der Ottilie in Goethes Roman Die Wahlverwandtschaften." JbdfdH 81 (1982): 82-96.

Novalis. "Die Christenheit oder Europa." Die deutsche Literatur in Text und Darstellung: Romantik I. Band 8. Eds. Otto F. Best and Hans-Jürgen Schmitt. Stuttgart: Philipp Reclam jun. GmbH \& Co., 1974. 161-182.

Novalis. "Die Welt muß romantisiert werden." Die deutsche Literatur in Text und Darstellung: Romantik I. Band 8. Eds. Otto F. Best and Hans-Jürgen Schmitt. Stuttgart: Philipp Reclam jun. GmbH \& Co., 1974. 57.

Novalis. "Fragmente zur Poetik." Die deutsche Literatur in Text und Darstellung: Romantik I. Band 8. Eds. Otto F. Best and Hans-Jürgen Schmitt. Stuttgart: Philipp Reclam jun. GmbH \& Co., 1974. 254-258.

Novalis. "Lehrlinge zu Sais." Die deutsche Literatur in Text und Darstellung: Romantik II. Band 9. Eds. Otto F. Best and Hans-Jürgen Schmitt. Stuttgart: Philipp Reclam jun. GmbH \& Co., 1974. 53-58. 
Reiss, Hans. "Mehrdeutigkeit in Goethes Wahlverwandtschaften." Jahrbuch des deutschen Schillergesellschaft 14 (1970): 366-396.

Schelling-Schär, Esther. "Die Gestalt der Ottilie: zu Goethes Wahlverwandtschaften. Zürich u. Freiburg i Breisgau: Atlantis Verlag, 1969.

Schlegel, Friedrich. "Progressive Universalpoesie." Die deutsche Literatur in Text und Darstellung: Romantik I. Band 8. Eds. Otto F. Best and HansJürgen Schmitt. Stuttgart: Philipp Reclam jun. GmbH \& Co., 1974. 2225.

Stöcklein, Paul. "Stil und Sinn der Wahlverwandtschaften." Wege zum Späten Goethe. Hamburg, 1949.

Stopp, F.J. "Ein wahrer Narziß: Reflections on the Eduard-Ottilie Relationship in Goethe's Wahlverwandtschaften." PEGS 29 (1959-60): 52-85.

Tieck, Ludwig. "Der blonde Eckbert." Die deutsche Literatur in Text und Darstellung: Romantik II. Band 9. Eds. Otto F. Best and Hans-Jürgen Schmitt. Stuttgart: Philipp Reclam jun. GmbH \& Co., 1974. 31-53.

Wackenroder, Wilhelm Heinrich. "Herzensergießungen eines kunstliebenden Klosterbruders." Die deutsche Literatur in Text und Darstellung: Romantik I. Band 8. Eds. Otto F. Best and Hans-Jürgen Schmitt. Stuttgart: Philipp Reclam jun. GmbH \& Co., 1974. 77-83.

Walzel, Oskar. "Goethes Wahlverwandtschaften in Rahmen ihrer Zeit." Goethe Jahrbuch 27 (1906): 166-206.

Wiese, Benno von. Der Mensch in der Dichtung. Düsseldorf: August Bagel Verlag, 1958. 